\title{
Government Ownership of Banks
}

\section{Citation}

La Porta, Rafael, Florencio Lopez-De-Silanes, and Andrei Shleifer. 2002. Government Ownership of Banks. The Journal of Finance 57, no. 1: 265-301. Portico. doi:10.1111/1540-6261.00422.

\section{Published Version}

doi:10.1111/1540-6261.00422

\section{Permanent link}

http://nrs.harvard.edu/urn-3:HUL.InstRepos:30747188

\section{Terms of Use}

This article was downloaded from Harvard University's DASH repository, and is made available under the terms and conditions applicable to Other Posted Material, as set forth at http:// nrs.harvard.edu/urn-3:HUL.InstRepos:dash.current.terms-of-use\#LAA

\section{Share Your Story}

The Harvard community has made this article openly available.

Please share how this access benefits you. Submit a story.

\section{Accessibility}




\title{
NBER WORKING PAPER SERIES
}

\section{GOVERNMENT OWNERSHIP OF BANKS}

\author{
Rafael La Porta \\ Florencio Lopez-de-Silanes \\ Andrei Shleifer \\ Working Paper 7620 \\ http://www.nber.org/papers/w7620
NATIONAL BUREAU OF ECONOMIC RESEARCH
1050 Massachusetts Avenue
Cambridge, MA 02138
March 2000

\begin{abstract}
We are grateful to Thorsten Beck, Simeon Djankov, Edward Glaeser, Simon Johnson, Ross Levine, and Dani Rodrik for helpful comments, to Karine Del Paso, Magdalena Lopez-Morton, Dmitry Rozhkov and Ekaterina Trizlova for research assistance, and to the National Science Foundation and the Dean's Research Fund at the Kennedy School of Government, Harvard University for financial support of this research. The views expressed herein are those of the authors and are not necessarily those of the National Bureau of Economic Research.
\end{abstract}

(C) 2000 by Rafael La Porta, Florencio Lopez-de-Silanes, and Andrei Shleifer. All rights reserved. Short sections of text, not to exceed two paragraphs, may be quoted without explicit permission provided that full credit, including (C) notice, is given to the source. 
Government Ownership of Banks

Rafael La Porta, Florencio Lopez-de-Silanes, and Andrei Shleifer

NBER Working Paper No. 7620

March 2000

JEL No.G21, L32, O4

\begin{abstract}
In this paper, we investigate a neglected aspect of financial systems of many countries around the world: government ownership of banks. We assemble data which establish four findings. First, government ownership of banks is large and pervasive around the world. Second, such ownership is particularly significant in countries with low levels of per capita income, underdeveloped financial systems, interventionist and inefficient governments, and poor protection of property rights. Third, government ownership of banks is associated with slower subsequent financial development. Finally, government ownership of banks is associated with lower subsequent growth of per capita income, and in particular with lower growth of productivity rather than slower factor accumulation. This evidence is inconsistent with the optimistic "development" theories of government ownership of banks common in the 1960 s, but supports the more recent "political" theories of the effects of government ownership of firms.
\end{abstract}

Rafael La Porta

Department of Economics

Harvard University

Littauer M7

Cambridge, MA 02138

and NBER

rafael_laporta@harvard.edu

Andrei Shleifer

Department of Economics

Littauer M9

Harvard University

Cambridge, MA 02138

and NBER

ashleifer@harvard.edu
Florencio Lopez-de-Silanes

Kennedy School of Government

Harvard University

79 JFK Street

Cambridge, MA 02138

and NBER

f_lopezdesilanes@harvard.edu 


\section{Introduction.}

This paper discusses a neglected aspect of financial systems of many countries:

government ownership of banks. It shows that such ownership is pervasive around the world, especially in countries with poor institutions, and that it has significant consequences for resource allocation and economic development.

There are two broad views of the government's participation in financial markets. The first, basically optimistic, "development” view is associated with Alexander Gerschenkron (1962), who focuses on the necessity of financial development for economic growth. Gerschenkron argues that privately owned commercial banks have been the crucial vehicle of channeling savings to industry in several industrializing countries in the second half of the $19^{\text {th }}$ century, especially Germany. However, in some countries -- most conspicuously Russia -- economic institutions were not sufficiently developed for private banks to play the crucial development role. "The scarcity of capital in Russia was such that no banking system could conceivably succeed in attracting sufficient funds to finance a large scale industrialization; the standards of honesty in business were so disastrously low, the general distrust of the public so great, that no bank could have hoped to attract even such small capital funds as were available, and no bank could have successfully engaged in long term credit policies in an economy where fraudulent bankruptcy had been almost elevated to the rank of a general business practice" (p. 19). In such countries, the government could step in and through its financial institutions jump start both financial and economic development. Thus in Russia in the 1890s, "it was the government that generally fulfilled the function of industrial banks" (p.22), with salutary effects.

Gerschenkron's view was part of a broader sentiment in development economics which 
advocated government ownership of firms in the strategic economic sectors (see Shleifer 1998 for a summary). W. Arthur Lewis (1950), for example, explicitly advocates government ownership of banks, as part of the "commanding heights" approach whereby the government would develop certain strategic industries through both direct ownership and control over finance. Myrdal (1968) is sympathetic toward government ownership of banks in India and other Asian countries. A few days before the October Revolution, Lenin laid out his own perspective on banking: "Without big banks, socialism would be impossible. The big banks are the 'state apparatus' which we need to bring about socialism, and which we take ready-made from capitalism..." (Lenin 1917, quoted in Garvy 1977, p. 21). These ideas were widely adopted around the world, particularly in the 1960s and the 1970s, with governments nationalizing the existing commercial banks and starting new ones in Africa, Asia, and Latin America.

In contrast, a more recent "political" view of government ownership holds that government control of finance, through its banks or otherwise, politicizes resource allocation for the sake of getting votes or bribes for office holders, softens budget constraints, and lowers economic efficiency (see, e.g., Kornai 1979, Shleifer and Vishny 1994). This view is buttressed by considerable evidence documenting the inefficiency of government enterprises, the political motives behind public provision of services, and the benefits of privatization (e.g, Megginson et al. 1994, Barberis et al. 1996, Lopez-de-Silanes, Shleifer and Vishny 1997, Frydman et al. 1999, La Porta and Lopez-de-Silanes 1999). Gerschenkron has some sympathy for this view: "There is no doubt that the government as an agens movens of industrialization discharged its role in a far less than perfectly efficient manner. Incompetence and corruption of bureaucracy were great. The amount of waste that accompanied the process were formidable.” (p. 20). Still, 
Gerschenkron considers government financing of industrialization in Russia a great success.

The government can participate in the financing of firms in a variety of ways: it can provide subsidies directly, it can encourage private banks through regulation and suasion to lend to politically desirable projects, or it can own financial institutions -- completely or partially -itself. The advantage of owning banks -- as opposed to regulating banks or owning all projects outright -- is that bank ownership gives the government extensive control over the choice of projects being financed while leaving the implementation of these projects to the private sector. Ownership of banks thus promotes the government's goals in both the "development" and the "political" theories. In the development theories, ownership of banks enables the government both to collect savings and to direct them toward strategic long term projects. Through such project finance, the government overcomes institutional failures undermining private capital markets, and generates aggregate demand and other beneficial externalities fostering growth. In the political theories, ownership of banks enables the government to finance the inefficient but politically desirable projects. In both theories, the government finances projects that would not get privately financed. In the development theories, these projects are socially desirable. In the political theories, they are not.

Using data on government ownership of banks from 92 countries around the world, we address four related questions. First, how significant is government ownership of banks in different countries? Second, what types of countries have more government ownership of banks? Third, does government ownership of banks promote subsequent financial development? Fourth, does government ownership of banks promote subsequent economic growth and, relatedly, how does it effect factor accumulation, savings, and growth of productivity? 
Both the development and the political view imply that government ownership of banks should be more prevalent in poorer countries, countries with less developed financial markets, and more generally, countries with less well functioning institutions. The development theories also imply that, other things equal, government ownership of banks should benefit subsequent financial and economic development, factor accumulation, and especially productivity growth. The political theories, in contrast, imply that, other things equal, government ownership of banks should displace (crowd out) the growth of private financing. Moreover, while government financing through its banks can encourage savings and capital accumulation, the projects the government finances are likely to be inefficient and have an adverse effect on productivity growth. By looking at financial development and productivity growth, we can thus attempt to distinguish the two theories of government ownership of banks.

Although our results support some elements of the development view, they are overall more favorable to the political view. We show, first, that government ownership of banks is common around the world: in an average country, 42 percent of equity of the 10 largest banks was still owned by the government in 1995. We also show that government ownership of banks is especially common in poor countries, as well as in countries with poorly defined property rights, heavy government intervention in the economy, and underdeveloped financial systems. The latter findings are consistent with Gerschenkron's idea of where governments are likely to own banks. However, our results on the effects of government ownership of banks on financial and economic development do not support Gerschenkron's optimism. We find that higher government ownership of banks is associated with slower subsequent development of the financial system, lower economic growth, and in particular lower growth of productivity. These results -- 
and particularly the finding of low productivity growth in countries with high government ownership of banks -- are broadly supportive of the political view on the effects of government interference in markets.

This research relates to a number of strands in the recent literature of financial development and economic growth. King and Levine (1993), Levine and Zervos (1998), Rajan and Zingales (1998), Beck, Levine, Loayza (2000), Levine (1999), and Wurgler (2000) all document the benefits of financial development for economic growth. Young (1995) shows that in several East Asian countries growth has taken the form of factor accumulation rather than productivity growth. Since the allocation of financial resources in East Asian economies is heavily politicized, our results suggest that the same problems that have influenced productivity growth in East Asia may be pervasive when the government controls the flow of capital.

Two recent papers consider government ownership of banks. Sapienza (1999) finds that Italian state-owned banks pursue political objectives in their lending policies, consistent with the political view. Barth, Caprio and Levine (1999) present a comprehensive data base on government regulation of banks around the world. Like our paper, they find that government ownership of banks is higher in countries with less developed financial systems. This result is consistent with both the political and the development views.

The next four sections deal with the four questions raised above: the pervasiveness of government ownership of banks, the characteristics of countries that have it, its effect on financial development, and its effect on the growth of output, factor accumulation, and growth of productivity. Section VI concludes. 
II. How common is government ownership of banks?

\section{Variable Definitions}

All the variables used in this paper are summarized in Table 1. We describe them at the time we introduce them into the analysis.

We analyze government ownership of large banks in 92 countries. We use Polk World Banking Profiles and the Thomson Bank Directory for 1996 to determine the number of countries with sufficient data on banks. For each country in the sample, we identify the 10 largest commercial or development banks (in terms of assets) that lend money to firms, regardless of their ownership structure and of whether or not they take deposits. We include development banks because their function is precisely to provide long term finance to development projects where private finance may fail (Myrdal 1968), and hence they constitute one prominent form of government entry into bank lending. Below we discuss the role of development banks at some length. We do not include Central Banks, Postal Banks (which generally do not lend money to firms and are described as non-banking institutions), investment banks, other specialized financial intermediaries (trust companies, home loan banks) or world-wide development banks such as the World Bank. If a country has fewer than 10 banks in Polk and Thomson, we add information where we can from Europa Yearbook and Euromoney Bank Register 1996.

We identify ownership structures of banks in this sample using company reports as well as national and international sources (Appendix A lists the sources for each country). Identifying state versus private ownership is usually straightforward, but there are a few judgment calls. First, we classify ownership by foreign governments as private rather than state ownership. This reduces estimates of state ownership, but makes analytical sense since foreign governments are 
less likely to support money-losing firms abroad. Second, we keep subsidiaries of foreign banks in the sample as long as they make loans and extend credit locally. Third, some development banks in the sample are regional, and owned by the governments of several countries. Some of these banks also have private owners, as well as ownership by multilateral agencies such as the World Bank. We take the equity ownership in a regional bank by a country's government as the estimate of the proportion of the bank's assets that are in that country. These steps give us estimates of government ownership of the 10 largest banks in each country.

Using these data, we compute five measures of government ownership of banks, each calculated to emphasize a somewhat different aspect of ownership. In all these calculations, we address the issue of indirect ownership by the government, i.e., governments owning shares in holding or other companies which in turn own shares in sample banks. The first measure, GB (government banking), is defined as follows. For each of the 10 largest commercial and development banks in a country, we first calculate the percentage of government ownership by multiplying the share of each shareholder in that bank by the share the government owns in that shareholder, and then summing the resulting shares:

$$
G B_{i k}=\sum_{j=1}^{J} s_{j i} s_{g j}
$$

where $k=1 \ldots .92$ indexes the countries in our sample, $i=1 \ldots .10$ indexes the ten largest banks in a country, $j=1 \ldots . J$ indexes shareholders of a given bank, $G B_{i k}$ stands for the government's share in bank $i$ in country $k, s_{j i}$ is the share of bank $i$ owned by shareholder $j$, and $s_{g j}$ is the share of equity the government owns in $j$ ( $s_{g j}=0$ if $j$ is a private individual). For example, the government of 
Israel owns $86.2 \%$ of the shares in Bank Leumi. In this case, $\mathrm{J}=1, s_{l i}=.862$ and $s_{g i}=1$ for this bank.

GB for a country $k$ is computed by multiplying $G B_{i k}$ of every sampled bank $i$ by its total assets, summing the resulting numbers and dividing the sum by total assets of the top 10 banks:

$$
G B_{k}=\frac{\sum_{i=1}^{10} G B_{k} a_{i k}}{\sum_{i=1}^{10} a_{i k}}
$$

where $G B_{k}$ is the first measure of government bank ownership for country $k$, and $a_{i k}$ are the total assets of bank $i$. GB is the simplest measure we use: it captures the share of the assets of the top 10 banks in a given country that is "owned" as opposed to "controlled" by the government.

GB reflects government ownership of banks in the mid 1990s, well after privatization of banks in many countries had gotten underway. Since we are ultimately interested in the effect of government ownership of banks on economic development, we need to estimate the percentage of banking assets owned by the government in the 1960s and 1970s, before privatizations. We could not determine fully the history of ownership of each bank back to 1960, but did come up with estimates of government ownership in our sample banks in 1985, roughly at the peak of government ownership around the world and before bank privatization had started in any country but Chile. Since we know which of the banks in our sample had been privatized after 1985, we can determine government ownership in these banks before privatization. This variable, GBBP -government banking before privatization, is constructed like GB, except that if a bank was 
privatized after 1985 , we set $\mathrm{GBBP}_{i k}$ equal to the percentage of that bank actually owned by the government before privatization. In the countries where we know that the entire banking system was owned by the government in 1985, including Sri Lanka, El Salvador, Nicaragua, Mexico and 12 socialist countries, we set GBBP $=1$. A possible problem with GBBP is that the top 10 list is taken in 1995, so we may underestimate government ownership in 1985 if large state owned banks circa 1985 were no longer the largest by 1995 . We use GBBP in the regressions. Since the correlation between GB and GBBP is .78, it does not matter which variable we use.

GB does not take into account the possibility that the extent of government control of a bank, particularly when the government is a large shareholder, may exceed its equity ownership. The next 3 variables, all based on government ownership in the mid-1990s, classify banks as "government-owned" when the government's equity ownership exceeds certain thresholds. We use these variables to make sure that our two basic variables do not produce a misleading answer.

To construct the next variable, GB20, we start with government ownership measures for each of the 10 largest banks. We then classify a bank as government-owned if $\mathrm{GB}_{i k}>.2$ and the government is the largest known shareholder or if $\mathrm{GB}_{i k}>.5$ (in case we do not know the percentage ownership by the largest shareholder). GB20 is the sum of assets of all governmentowned banks using this definition (among the 10 largest) divided by the total assets of 10 largest banks in the country. This approach is in line with our earlier work which suggests that $20 \%$ ownership is typically sufficient for control (La Porta, Lopez-de-Silanes, and Shleifer 1999). Along similar lines, we construct GB50 as a ratio of the assets of the banks in which the government holds over $50 \%$ of equity to the total assets of the 10 largest banks; and GB90 as a corresponding measure for banks where government equity ownership exceeds $90 \%$. Before 
presenting the results, we note that these measures of government ownership of banks are highly correlated with each other: the correlation between GB and GB20 is .95; the correlation between GB and GB50 is .97, and the correlation between GB and GB90 is .92. The correlations between these variables and GBBP are in the $.7-.8$ range.

\section{Findings}

Table 2 presents our basic findings on the extent of government ownership of banks. We divide countries into groups by the origin of their commercial laws (common law, French civil law, German civil law, Scandinavian law and socialist law). Our previous research shows that the nature of both financial markets and government involvement in economic life differs significantly across legal origins (La Porta et al., or LLSV, 1997, 1998, 1999).

Government ownership of banks is large and pervasive around the world. Even looking at the 1995 data, after bank privatization had been completed in many countries, the world mean of government ownership is 41.7 percent, and a somewhat lower 38.7 percent if we exclude the former socialist countries. The corresponding number for pre-privatization ownership is an even higher 55 percent (and 48.3 percent if we exclude the former socialist countries). The magnitude of the post-privatization number suggests that, while privatization has made a dent in government ownership of banks, it has not reduced it to negligible levels.

Our adjustments for government control relative to cash flow ownership also increase the world average compared to the basic variable. Using GB20 to measure government control, the world average share of banking assets controlled by the government is 48 percent ( 43.9 percent without former socialist countries). As we illustrate below, these magnitudes are considerably 
higher than the measures of government participation in more general economic activity such as production or investment. These findings establish our first proposition: government ownership of banks is very large -- even after the wave of privatizations.

It is also pervasive across continents and legal origins of commercial laws. Outside of the few rich common law countries and Japan (at the time we took the measurement), governments nearly everywhere own a respectable share of bank equity. The common law average is a high 28.5 percent (37.2 percent before privatization), though still statistically significantly lower than the French civil law origin average of 45.5 percent ( 56.3 percent before privatization). As is often in these comparisons of financial structures, the German and the Scandinavian averages are between the English and French ones, and close to each other. The former socialist countries still have the highest average share of equity of the largest banks owned by the government ( 61.8 percent), although this share is down sharply from 100 percent 10 years ago. The corrections for government control change these numbers somewhat, but do not alter the general picture of high and pervasive government ownership of banks, occurring nearly everywhere but especially in French civil law and socialist law countries.

Table 2B examines the importance of development banks in our sample. Its first column shows, by legal origin, how much of the government ownership of top 10 banks is accounted for by government ownership of development banks. On average, about 5.3 percent out of 41.7 percent overall level of government ownership is accounted for by development banks. Development banks are particularly prevalent in French legal origin countries (largely in Latin America), and utterly uncommon in German, Scandinavian, and socialist origin countries. The second column of Table 2B reproduces the averages of GB from Table 2, and the 
third column shows how these averages change when we take development banks out of the sample (i.e., both the numerator and the denominator in the definition of GB). The corrected variable, government ownership of commercial banks or GBC, has a worldwide average of 38.4 percent (compared to 41.7 percent for GB). The difference between French and English origins remains large, though not longer statistically significant.

Conceptually, we believe it is appropriate to include development banks in the sample, since in some countries these are precisely the banks allegedly addressing the GerschenkronMyrdal development problems. We therefore keep these banks in the results we present. To be safe, we have redone every regression excluding them. The statistical significance of some results falls a notch, but the important results presented below remain statistically significant.

The results on the differences in government ownership of banks among legal origins are in principle consistent with both the development and the political view. Earlier research (LLSV 1997, 1998) shows that countries with French legal origin laws have less investor protection and less developed private financial markets than do common law countries, which on the development view would increase the demand for government provision of finance. Other research (LLSV 1999) shows that French legal origin countries in general intervene more in economic life. Consistent with the political view, then, government ownership of banks may be a reflection of the greater politicization of economic activity in French legal origin (and socialist) countries than in common law countries. In the subsequent sections, we present further evidence that attempts to distinguish the two theories. Importantly, all the results presented below have been rerun excluding socialist countries, and none of the conclusions we draw depend on them. 
III. Which countries have high government ownership of banks?

In this section, we ask which characteristics of countries predict high government ownership of banks. We do so by first considering the correlations between various country characteristics and our first two measures of government ownership of banks (after and before privatization). Because these correlations may be influenced by the fact that poorer countries generally have higher GB and GBBP, we also present the coefficients from regressions of government ownership of banks on country characteristics, a constant, and the log of 1960 per capita GDP. These results crudely correct for the differences in per capita incomes.

Table 1 describes all the data used in this paper, including the country characteristics we examine. An important point should be noted. Due to data availability, most of the country characteristics we examine come either from the 1990s, or alternatively are averages of the data from 1975 to 1995, i.e., either at the same time as GB or later than GBBP. We cannot therefore argue that these country characteristics in some ways cause high government ownership of banks. Rather, we are only looking at correlations, without structural interpretations. For one important set of measures, namely those of the level of private financial development, we have data starting in 1960 and in 1970, and hence can ask more dynamic questions.

We begin the analysis with the 1960 level of per capita income, simply to point out that poorer countries indeed have more government ownership of banks. We then examine a number of indicators of the quality of government, some of which we have studied in an earlier paper (LLSV 1999). These include measures of government intervention in economic life (such as regulation, price controls, black market premium, political rights, and government spending), measures of the efficiency of government (such as tax compliance, corruption and bureaucratic 
quality), measures of the security of property rights, rule of law, and investor protection, measures of the importance of state-owned firms in the overall economy as opposed to just in banking, measures of initial levels of financial development, and finally, measures of the incidence of political and financial crises in the economy.

Table 3 focuses on post-privatization government ownership of banks. Panel A establishes that such ownership is higher in countries that were poorer in 1960. In the subsequent panels, in addition to correlations, we present the coefficients from regressions controlling for (the logarithm of) 1960 per capita income. Panel B shows that countries with more interventionist governments also have higher government ownership of banks. Heavier regulation, higher frequency of price controls, heavier banking regulation, and higher black market exchange rate premiums are all associated with greater government ownership of banks, even controlling for initial per capita income. These correlations are high and statistically significant. At the same time, there is no relationship between the size of government, as measured by government consumption or government transfers and subsidies relative to GDP, and government bank ownership. This may be partly due to the fact that these measures of government spending are high in developed market economies, which generally have both big and good government (LLSV 1999). Finally, the evidence shows that government ownership of banks is lower in countries that have wider political rights or are more democratic. Social as well as economic interventionism is associated with higher government ownership of banks.

Panel C considers government efficiency, which is related to interventionism but is not necessarily the same thing. Countries with less efficient governments have greater government ownership of banks. Higher tax compliance, higher bureaucratic quality, and lower corruption are 
all associated with lower government ownership of banks. The corruption index is not statistically significant in a regression controlling for income, but other variables are.

Panel D focuses on the security of property rights. The first three variables -- the property rights index, rule of law, and the likelihood of government repudiation of contracts -- all show that countries with greater security of property rights have lower GB. This result is consistent with Gerschenkron's emphasis on poor protection of property rights in Russia as the reason why government participation in financial markets was necessary. There is also weak evidence that countries with higher LLSV (1998) indices of shareholder and creditor rights have lower government ownership of banks.

Panel E examines the relationship between government ownership of banks and measures of the importance of state owned enterprises (SOEs) in the economy, including an index of their prevalence as well as measures of relative output, investment, and employment of SOEs. Not surprisingly, countries with greater roles of SOEs in the economy also have higher government ownership of banks. Perhaps a more interesting question is how the government ownership of large banks compares to the measures of the importance of SOEs. Figures 1 and 2 present the relevant plots. On average, government ownership of banks is higher than the measures of the relative size of the SOEs in the economy. The numbers presented here are not, however, directly comparable, since we do not consider the smaller banks, where government ownership may be lower.

Panel F examines the relationship between government ownership of banks and measures of financial, particularly banking, development. Our preferred measures of banking development follow Beck, Levine, and Loayza (2000). These authors choose and defend theoretically three 
variables: credit by financial intermediaries to the private sector relative to GDP, liquid liabilities of the financial system relative to GDP, and a ratio of commercial bank domestic assets to commercial plus central bank domestic assets. We also agree with Beck et al. that the first of these measures is theoretically the most satisfactory. For the period starting in 1970, we have further measures of financial development: the ratio of quasi-liquid liabilities to GDP, the ratio of domestic credit to the banking sector to GDP, and the ratio of claims on the private sector to GDP. The data on the first three variables in Panel F are for 1960, and on the second three for 1970 (in which case we control for $1970 \log$ per capita GDP in the regressions.)

The data in Panel F show negative correlations between these measures of financial development and government ownership of banks, though the results are only occasionally significant. This evidence is consistent with both the development view that the government steps in to help in the underdeveloped financial systems, and the political view that the government displaces private financial institutions when it politicizes resource allocation.

Finally, in Panel G we examine the question of whether government ownership of banks is associated with economic and political instability, as measured by inflation, the incidence of political crises and coups, as well as the incidence and depth of banking crises. The data on banking crises pertain to the period 1970-1990. Here causality is a particularly thorny issue, since government ownership may be a cause of instability because of politicized lending, but may also be a response to instability through nationalizations. Ironically, except for some weak evidence that countries with higher inflation have higher government ownership of banks, the association between such ownership and the available measures of instability is weak. This may be because of the timing problems in the data. Alternatively, such factors as the general interventionist stance of 
the government, its efficiency, and the security of property rights may be more important correlates of government bank ownership than are the assorted crises.

We have redone this analysis using the pre- rather than post-privatization measure of government ownership of banks. The results are extremely similar both in terms of the coefficients and in terms of the patterns of statistical significance. In our growth analyses in the following sections, we use GBBP, since it stands a better chance of being predetermined relative to the growth experiences we study. Recall that the correlation between GB and GBBP is .78.

The evidence in this section is consistent with both the development and the political views of government ownership of banks. Countries with high government ownership of banks are indeed more backward and more statist: they are poorer, have more interventionist and less efficient governments, as well as less secure property rights. There is weak evidence that countries with less developed financial systems have higher government ownership of banks. Are these interventionist and inefficient governments able to step in and, through their ownership of banks, jump start the financial system and accelerate development, consistent with the development view? Alternatively, do such governments simply politicize resource allocation without much benefit to growth, consistent with the political view? In the next two sections, we attempt to address these questions.

IV. Does government ownership of banks speed up financial development?

Gerschenkron suggests that the government, by participating in the financial sector, can encourage the subsequent development of private lending, as it evidently did in Russia at the end of the $19^{\text {th }}$ century. The government may help to develop the institutions of lending such as 
standardized contracts or specialized courts, show by example that long term lending is possible and profitable, or simply subsidize private banks. In this section, we consider the growth of the measures of financial development introduced in Panel F of Table 3 as a function of initial levels of financial development and per capita income as well as of our measure of pre-privatization government ownership of banks.

The results are presented in Table 4. The first panel considers the growth in Beck, Levine and Loayza's (2000) measures of financial development between 1960 and 1995 as a function of 1960 initial conditions and GBBP; note that we have extended their sample to cover 89 countries. The second panel considers the growth in all six measures of financial development between 1970 and 1995 as a function of 1970 conditions and GBBP. Two results stand out in this Table. First, the initial level of financial development is negatively correlated with its own subsequent growth. This may be a statistical artefact, or simply reflect some convergence in financial development. Second, government ownership of banks ceteris paribus reduces subsequent financial development. Using growth since 1960, this effect is only statistically significant at the 10 percent level for our preferred variable -- the growth in the ratio of private credit to GDP. However, for the post-1970 period, this effect has some statistical significance for 4 out of 6 measures of financial development.

These results are inconsistent with the development view of government ownership of banks. They are, however, consistent with the political view.

V. Does Government Ownership of Banks Speed Up Economic Growth?

In this section, we examine the effects of government ownership of banks on capital 
accumulation, savings, and productivity growth.

Table 5 presents growth regressions for the periods 1960-1995 and 1970-1995, where the dependent variable is the growth in per capita income. In Panel A, we include only the initial per capita income and GBBP. The results confirm the standard "convergence" finding, namely that initially poorer countries grow faster (Barro 1991). In addition, for both time periods, higher GBBP is associated with statistically significantly slower economic growth. A parameter estimate of around -2.5 suggests that, as ownership rises by 10 percentage points, growth falls by .25 percent per annum -- by no means a small effect. Although this result requires a number of qualifications and robustness checks, taken up below, on its face it does not support the development view that government participation in finance promotes economic development.

In Panel B, we control for average years of schooling, as is standard in growth regressions. The coefficient on GBBP falls by about $20 \%$, but remains statistically significant. In Panel C, we add alternatively the three measures of initial financial development from Beck, Levine and Loayza (2000). For two out of three measures, including the initial private credit relative to GDP, the initial level of financial development exerts a positive influence on future growth, consistent with the work of Levine and his co-authors. Yet holding initial financial and economic development as well as schooling constant, GBBP continues to exert a large and statistically significant negative effect on subsequent growth. The coefficient remains between 1.5 and -2 . Controlling for the traditional variables in the growth regressions, government ownership of banks has a negative impact on subsequent economic growth.

One concern with these specifications is that GBBP may simply proxy for some alternative measure of distortionary economic policies or poorly protected property rights. These policies, 
rather than government ownership of banks per se, may retard economic growth (Knack and Keefer 1995). After all, we have already shown that government ownership of banks is more prevalent in countries with interventionist and inefficient governments, as well as poorly protected property rights. In Table 6, we include some of the standard measures of government intervention, using to the extent possible the earliest data available so that we can interpret these variables as having a possible causal effect on growth. The inclusion of some of these variables may spuriously reduce the effect of GBBP. In all these regressions, we include initial private credit relative to GDP, initial economic development, average years of schooling, as well as a number of geographic controls to address the spurious correlation issue.

Measures of government distortions do not eliminate the statistical significance of the effect of GBBP on subsequent growth. The coefficient stays at around -1.5 indicating a large effect on growth. In contrast, the distortions we measure do not themselves have statistically significant effects on future growth when included in the regression with GBBP.

Following Beck, Levine and Loayza (2000), we next consider specific channels through which government ownership of banks can influence economic growth. Panel A of Table 7 focuses on savings and capital accumulation. There is some evidence that initial per capita income exerts a negative influence on capital accumulation, and a positive influence on savings. There is also evidence that higher years of schooling are associated with higher capital accumulation. Finally, there is some unsurprising evidence that greater initial financial development is associated with faster subsequent capital accumulation, consistent with Beck et al.(2000). However, there does not appear to be much evidence that government ownership of banks has a significant influence on either capital accumulation or savings. The tiny positive (but insignificant) effect of 
government ownership of banks on savings provides mild support for the development view, although the increased savings -- to the extent that there are any -- do not seem to go into capital formation.

Panel B of Table 7 focuses on the growth in productivity. Following Beck, Levine and Loayza (2000), we consider three measures of productivity growth (see Table 1 for exact definitions). The first measure derives productivity growth as output growth adjusted for capital accumulation. The second and third measures also adjust output growth estimates by the growth of human capital. We have been able to expand the Beck et al. sample from 61 to 77 countries for their first two measures of productivity growth, but not for the third one, since the data needed for the last productivity measure were not available for the extra countries. As in the various specifications, we also use the controls introduced earlier.

The results on productivity growth are striking. GBBP exerts a negative and, in most specifications, statistically significant effect on future productivity growth, even controlling for initial financial development and schooling. The coefficients, depending on the specification, are between -1 and -2 , indicating that a 10 percentage point higher measure of government ownership is associated with .1 to .2 percent per annum lower rate of productivity growth. The bottom line of these results is that productivity is the place where government ownership of banks negatively impacts growth.

This evidence is broadly consistent with the political view according to which government ownership creates resource misallocations that are detrimental to productivity growth and ultimately economic growth itself. The evidence on resource misallocation is also consistent with Sapienza's (1999) findings for Italian banks, as well as with a large literature on state firms. 
Finally, the data support Young's (1995) interpretation of Asian growth. The evidence is not, however, consistent with the development view of the beneficial effects of government ownership of banks on productivity growth.

Table 8 presents some additional tests of the political theory, by asking what effects government ownership of banks has on two rough proxies of the efficiency of resource allocation. First, does the share of private credit that goes to firms outside the top 20 depend on government ownership of banks? If that share is lower when GBBP is higher, it may suggest that when a government controls banks it allocates a lion share of the credit to the largest firms, thereby depriving the smaller firms of credit. Second, is the spread between the lending and the deposit rate increasing with government ownership of banks? If it is, government ownership may reduce the efficiency of the banking sector itself.

Table 8 shows that countries with higher GBBP allocate a lower share of private credit to firms outside the top 20. Countries with a higher GBBP also have higher markups in the banking sector. This evidence is consistent with the view that government ownership of banks is associated with a misallocation of resources in the economy.

One possible concern about our growth analysis is the endogeneity of government ownership of banks. We have presented in Table 3 some evidence indicating that financial and economic crises do not appear to be good predictors of government ownership. But there remains a concern that some deeper structural factors both cause government ownership of banks and slow down the growth of productivity and output. Although there is no perfect way to address this concern, we can try to address it in part by using instrumental variables to predict government ownership of banks. As instruments, we use the variables that have been introduced 
in our earlier work (LLSV 1997, 1998, 1999), and have been previously used in a similar context by Beck, Levine and Loayza, namely legal origins and religious compositions of the populations in different countries. These variables have the advantage of being historically predetermined, correlated with government ownership of banks (see Table 2), and possibly uncorrelated with the residual.

Table 9 presents the results of these instrumental variable regressions for the growth of income, growth of capital, savings rates, and productivity growth, using various control variables. In most specifications, the instrumental variable results are similar to the OLS results, although the magnitude of the coefficients on GBBP in some instances increases sharply. The predicted component of GBBP exerts a sharp negative effect on both the growth in income and the growth in productivity, although not on capital accumulation and savings. In some productivity specifications, the coefficient rises by a factor of 3 from its OLS levels, implying very large effects on productivity growth. The last column in Table 9 presents the results of Lagrange Multiplier tests of the null hypothesis that our instruments are uncorrelated with the residuals. The tests do not reject the null hypothesis that the instruments are appropriate at the 5 percent or the 1 percent significance levels. The instrumental variable results corroborate our earlier findings and support the political view of government ownership of banks as detrimental rather than helpful to economic development. There always remains a possibility, however, that some omitted factor both increases the desirable level of government ownership of banks and reduces economic growth.

Finally, Table 10 presents a somewhat different perspective on the development thesis. In principle, it could be argued that the benefits of government ownership of banks appear only in 
backward countries with extremely poorly developed economic, financial, and property rights regimes. By grouping all countries into a regression, we may have failed to test this theory correctly. In Table 10, we reproduce some of our analyses by dividing the sample into the relatively rich and relatively poor countries as of 1960, relatively financially developed and relatively financially underdeveloped countries as of 1960, and countries with good and poor protection of property rights, for which an assessment is only available for the 1990s. The results do not support the development thesis: GBBP has a particularly adverse effect on the growth of income in the more backward countries, namely those with lower initial income, lower initial financial development, and weaker property rights protection. In the more advanced countries, the effect of GBBP on growth is still negative but often statistically insignificant. Perhaps the richer countries can get around the distortions associated with heavy government involvement in the financial sphere, whereas the more backward countries cannot, and pay with a sharply lower rate of growth of output and productivity.

\section{Conclusion.}

In this paper, we investigated a neglected aspect of financial systems of many countries around the world: government ownership of banks. The data shed light on four issues. First, government ownership of banks is large and pervasive around the world. Second, such ownership is larger in countries with low levels of per capita income, underdeveloped financial systems, interventionist and inefficient governments, and poor protection of property rights. Third, government ownership of banks is associated with slower subsequent financial development. Finally, government ownership of banks is associated with lower subsequent growth of per capita 
income, and in particular with lower productivity growth rather than slower factor accumulation. These retarding effects of government ownership of banks appear to be especially significant in the less developed countries.

Some aspects of the empirical story are consistent with the 1960s development economics view that government ownership of banks may arise as a response to institutional and financial underdevelopment. However, the results reject the optimistic assessment inherent in this view of the beneficial consequences of such ownership for subsequent development, advanced by Gerschenkron (1962), Myrdal (1968) and others. In contrast, the results are consistent with the political view of government ownership of firms, including banks, according to which such ownership politicizes the resource allocation process and reduces efficiency. Ultimately, and in line with the latter theories, government ownership of banks retards financial and economic development, especially in poor countries. 


\section{References.}

Barberis, Nicholas, Maxim Boycko, Andrei Shleifer, and Natalia Tsukanova (1996), "How Does Privatization Work? Evidence from the Russian Shops," Journal of Political Economy 104, 764-790.

Barro, Robert (1991), "Economic Growth in a Cross-section of Countries," Quarterly Journal of Economics 56, 407-443.

Barro, Robert and Jong-Wha Lee (1996), "International Measures of Schooling Years and Schooling Quality," American Economic Review Papers and Proceedings 86, 218-223.

Barth, James, Gerard Caprio, Jr., and Ross Levine (1999), "Banking Systems Around the Globe: Do Regulation and Ownership Affect Performance and Stability?” World Bank Mimeo.

Beck, Thorsten, Levine, Ross and Norman Loayza (2000), "Finance and the Sources of Growth," Journal of Financial Economics, forthcoming.

Caprio, Gerald Jr. and Danieal Klingebiel (1996), "Banking Insolvencies: Cross Country Experience," Manuscript, World Bank.

Easterly, William and Ross Levine (1997), “Africa's Growth Tragedy: Policies and Ethnic Divisions," Quarterly Journal of Economics 112, 1203-1250.

Frydman, Roman, Cheryl Gray, Mark Hessel, and Andrzej Rapaczynski (1999), "Private Ownership and Corporate Performance: Evidence from the Transition Economies," Quarterly Journal of Economics 114, 1153-1192.

Garvy, George (1977), Money, Financial Flows, and Credit in the Soviet Union, Cambridge, MA: Ballinger Publishing Company for the National Bureau of Economic Research. Gerschenkron, Alexander (1962), Economic Backwardness in Historical Perspective, Cambridge, 
MA, Harvard University Press.

Hall, Robert and Charles Jones (1999), "Why Do Some Countries Produce so Much More Output per Worker than Others?” Quarterly Journal of Economics 114, 83-116.

King, Robert, and Ross Levine (1993), "Finance and Growth: Schumpeter Might be Right," Quarterly Journal of Economics 108, 717-738.

Knack, Stephen and Philip Keefer (1995), “Institutions and Economic Performance: Crosscountry Tests Using Alternative Institutional Measures," Economics and Politics 7, 207227.

Kornai, Janos (1979), "Resource-constrained vs. Demand-constrained Systems,” Econometrica 47, 801-819.

La Porta, Rafael and Florencio Lopez-de-Silanes (1999), “The Benefits of Privatization: Evidence from Mexico," Quarterly Journal of Economics 114, 1193-1242.

La Porta, Rafael, Florencio Lopez-de-Silanes, Andrei Shleifer (1999), “Corporate Ownership around the World," Journal of Finance 54, 471-517.

La Porta, Rafael, Florencio Lopez-de-Silanes, Andrei Shleifer and Robert W. Vishny (1997), “Legal Determinants of External Finance,” Journal of Finance 52, 1131-1150.

La Porta, Rafael, Florencio Lopez-de-Silanes, Andrei Shleifer and Robert W. Vishny (1998), “Law and Finance," Journal of Political Economy 106, 1113-1155.

La Porta, Rafael, Florencio Lopez-de-Silanes, Andrei Shleifer and Robert W. Vishny (1999), “The Quality of Government," Journal of Law, Economics and Organization 15, 222279.

Levine, Ross (1999), “Law, Finance, and Economic Growth,” Journal of Financial 
Intermediation, forthcoming.

Levine, Ross and Sara Zervos (1998), "Stock Markets, Banks, and Economic Growth," American Economic Review 88, 537-558.

Lewis, W. Arthur (1950), The Principles of Economic Planning, London: G. Allen \& Unwin. Lopez-de-Silanes, Florencio, Andrei Shleifer and Robert Vishny (1997), "Privatization in the United States," Rand Journal of Economics 28, 447-471.

Megginson, William L., Robert C. Nash and Mathias van Randenborgh (1994), "The Financial and Operating Performance of Newly Privatized Firms: an International Empirical Analysis," Journal of Finance 49, 403-452.

Myrdal, Gunnar (1968), Asian Drama, New York: Pantheon.

Rajan, Raghuram and Luigi Zingales (1998), "Financial Dependence and Growth,” American Economic Review 88, 559-586.

Sapienza, Paola (1999), "What do State-Owned Firms Maximize? Evidence from the Italian Banks," Northwestern University Mimeo.

Shleifer, Andrei (1998), "State vs. Private Ownership," Journal of Economic Perspectives 12, $133-150$.

Shleifer, Andrei and Robert Vishny (1994), "Politicians and Firms," Quarterly Journal of Economics 109, 995-1025.

Wurgler, Jeffrey (2000), "Financial Markets and the Allocation of Capital," Journal of Financial Economics, forthcoming.

Young, Alwyn (1995), "The Tyranny of Numbers: Confronting the Statistical Realities of East Asian Growth Experience," Quarterly Journal of Economics 110, 641-680. 


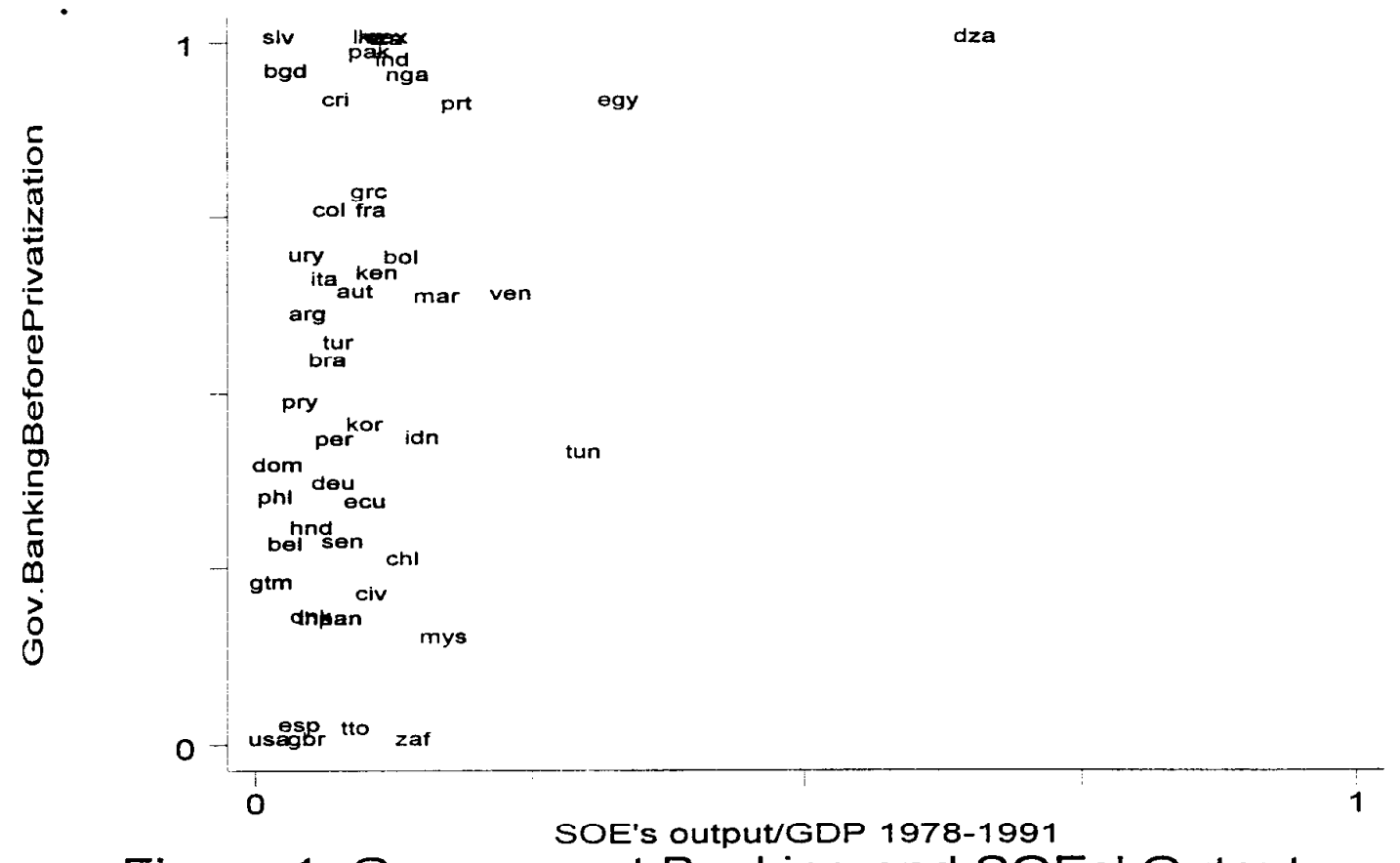

Figure 1: Government Banking and SOEs' Output 


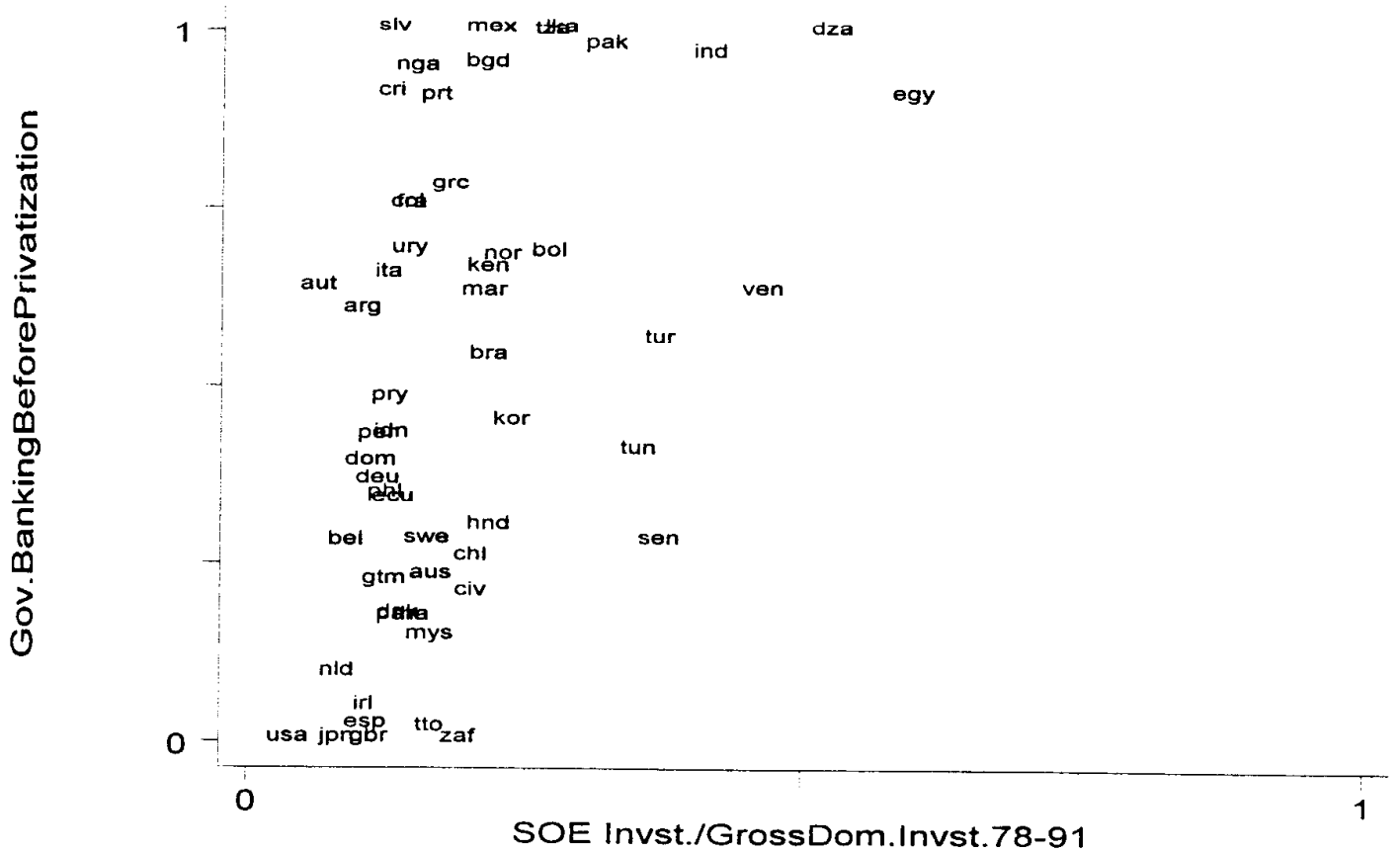

Figure 2: Government Banking and SOEs' Investment 
Table 1

Description of the variables

\begin{tabular}{|c|c|c|}
\hline Variable name & Description and source & $\begin{array}{l}\text { Number of } \\
\text { observations }\end{array}$ \\
\hline
\end{tabular}

Government banking

Government ownership of Share of the assets of the top 10 banks in a given country owned by the government of that country in 1995 . The percentage banks of the assets owned by the government in a given bank is calculated by multiplying the share of each shareholder in that bank by the share the government owns in that shareholder, and then summing the resulting shares. Source: Authors calculations

Government ownership of banks before privatization [GBBP]

Government ownership of banks at $20 \%$

[GB20]

Government ownership of banks at $50 \%$

[GB50]

Government ownership of banks at $90 \%$

[GB90]

Government ownership of development banks [GBD]

Government ownership of Commercial banks [GBC]

Government ownership of commercial banks before privatization [GBBPC]
Share of the assets of the top 10 banks in a given country owned by the government of that country in 1985. Used as a proxy for the percentage of banking assets owned by the government before the privatizations in the 1960s and 1970s. The percentage of assets owned by the government in a given bank is calculated following the same methodology outlined for GB. Source: Authors calculations based on various sources described in the Appendix A.

Share of assets of the top 10 banks in a given country controlled by the government at the 20 percent level in 1995 . A bank is controlled by the government if GB is larger than 20 percent and the state is the largest shareholder. Source: Authors calculations based on various sources described in the Appendix A.

Share of the assets of the top 10 banks in a given country controlled by the government at the 50 percent level in 1995 . Government ownership at the 50 percent level is defined as the government having at least 50 percent ownership. The percentage of assets owned by the government in a given bank is calculated following the same methodology outlined for GB. Source: Authors calculations based on various sources described in the Appendix A.

Share of the assets of the top 10 banks in a given country controlled by the government at the 90 percent level in 1995 . Government ownership at the 90 percent level is defined as the government having at least 90 percent ownership. The percentage of assets owned by the government in a given bank is calculated following the same methodology outlined for GB. Source: Authors calculations based on various sources described in the Appendix A.

Share of the assets of the top 10 banks in a given country owned by the government and reported to be development banks in 1995. The percentage of assets owned by the government is calculated following the same methodology outlined for GB. Source: Authors calculations based on various sources described in the Appendix A.

Same definition as GB except that it excludes development banks from the calculation of both government ownership and total assets of the top 10 banks in a given country. Source: Authors calculations based on various sources described in the Appendix A.

Same definition as GBBP except that it excludes development banks from the calculation of both government ownership and total assets of the top 10 banks in a given country. Source: Authors calculations based on various sources described in the Appendix A.

Initial level of development

Log of GDP per capita $\quad$ Logarithm of GDP per capita expressed in current US dollars in 1960 and in 1970. Source: International Financial

\section{Government intervention}

Business regulation index

Frequency of price controls index

Government intervention in the banking sector index

Black market premium
An index of regulation policies related to opening a business and keeping open a business (on a scale from 1 to 5). A high score indicates that regulations are straight-forward and applied uniformly to all businesses and that regulations are less of a burden to business. The score refers to the index in 1997. Source: 1997 Index of Economic Freedom.

An index of frequency of price controls imposed by the government that interfere with the freedom of buyers and sellers to undertake exchanges even though the terms of trade are mutually agreeable. Indicates the extent to which companies can set prices freely: 0=not at all, 10=very much so. Average of indices for 1989 and 1994, which are the only available. Source: Economic Freedom of the World 1975-1995.

An index of the degree of openness of a country's banking system. Specifically, the index accounts for the following: how difficult it is to open domestic banks; how heavily regulated the banking system is; the degree of government influence over the allocation of credit; whether banks are free to provide customers with insurance, sell real estate, and invest in securities; and whether foreign banks are able to operate freely. The scale is from 1 to 5 . A high score means that: there are very few restrictions on banks, that they can engage in all types of financial services, that governments controls few commercial banks and that there is no government deposit insurance. The score refers to the index in 1997. Source: 1997 Index of Economic Freedom.

Natural logarithm of 1 plus the average exchange rate black market premium meausred for the 1960s and the 1980s Source: Easterly and Levine (1997) and own calculations. 
Government consumption / GDP

Transfers and subsidies / GDP

Top marginal tax rate

Index of government intervention in the economy 1975

Index of Liberty 1980s

Political rights index
Government consumption expenditures as a percentage of GDP (scale from 0 to 100). Average for the years 1971-1995. Government consumption expenditures "include all spending on goods and services purchased by the government -things like national defense, road maintenance, wages and salaries, office space, and government owned vehicles. Since it is obtained from the national income accounts, it includes all levels of government spending. It does not include direct transfers and subsidies since these do not enter into the national income accounts". Source: Economic Freedom of the World, 1975 1995 (with data from the World Bank and the International Monetary Fund).

Total government transfers and subsidies as a percentage of GDP (scale from 0 to 100). Average for the years 1974-1994 Source: Economic Freedom of the World, 1975-1995 (with data from the World Bank and the International Monetary Fund).

The top marginal tax rate imposed by the government on high income levels. Average of the 1975-1995 period. Source: Economic Freedom of the World, 1975-1995.

A composite index constructed from all the government intervention measures in Economic Freedom of the World: government consumption to GDP, SOE in the economy index, frequency of price controls index, entry regulation index, legal system (equality of citizens under the law and access to non-discriminatory judiciary), government intervention and regulation causing negative interest rates. Scale ranging from 0 to 10,10 indicating minimal or no government intervention. Source: Economic Freedom of the World, 1975-1995.

Index calculated following principal component techniques for a set of 15 liberty indicators including: foreign exchange regime, military draft freedom, freedom of property, freedom of movement, freedom of information, civil rights freedom, economic systems, freedom of print media, freedom of broadcast media, freedom to travel domestically, freedom to travel abroad, freedom to peaceful assembly, no permit required to work, public search without warrant, and arbitrary seizure of property. Different years for the different indicators, all of them for the 1980s. Source: Rating Global Economic Freedom, 1992.

Index of political rights. Higher ratings indicate countries that come closer " to the ideals suggested by the checklist questions of: (1) free and fair elections; (2) those elected rule; (3) there are competitive parties or other competitive political groupings; (4) the opposition has an important role and power; and (5) the entities have self determination or a very high degree of autonomy". Source: Freedom House, 1996.
Bureaucratic quality index

High scores indicate "autonomy from political pressure" and "strength and expertise to govern without drastic changes in policy or interruption in government services". Scale from 0 to 10, with higher score indicating greater efficiency. Average of the month of April and October of the monthly index between 1982 and 1995. Source: International Country Risk Guide, 1996.

Corruption index

An index of corruption in government. Scale from 0 to 10. Low ratings indicate "high government officials are likely to demand special payments" and "illegal payments are generally expected throughout lower levels of government" in the form of "bribes connected with import and export licenses, exchange controls, tax assessment, policy protection, or loans." Average of the months of April and October of the monthly index between 1982 and 1995. Source: International Country Risk Guide, 1996

\section{Property rights}

Property rights index

Rule of law index

Government repudiation of contracts index
An index of property rights in each country (on a scale from 1 to 5). The more protection private property receives, the higher the score. The score is based, broadly, on the degree of legal protection of private property, the extent to which the government protects and enforces laws that protect private property, the probability that the government will expropriate private property, and the country's legal protection to private property. Source: Freedom House, 1996.

Assessment of the law and order tradition in the country produced by the country-risk rating agency International Country Risk Guide. Average of the month of April and October of the monthly index between 1982 and 1995. Scale from 0 to 6. Lower scores indicate less tradition for law and order . Source: International Country Risk Guide, 1996.

An index of ICRG's assessment of the "risk of a modification in a contract taking the form of a repudiation, postponement, or scaling down" due to "budget cutbacks, indigenization pressure, a change in government, or a change in government economic and social priorities." Average of the months of April and October of the monthly index between 1982 and 1995. 

mail their proxy vote to the firm; (2) shareholders are not required to deposit their shares prior to the General Shareholders' Meeting; (3) cumulative voting or proportional representation of minorities in the board of directors is allowed; (4) an oppressed minorities mechanism is in place; (5) the minimum percentage of share capital that entitles a shareholder to call for an Extraordinary Shareholders' Meeting is less than or equal to 10 percent (the sample median); or (6) shareholders have preemptive rights that can only be waved by a shareholders' vote. The index ranges from 0 to 6. Source: La Porta, Lopezde-Silanes, Shleifer, and Vishny (1998).

Creditor rights index

An index aggregating different creditor rights. The index is formed by adding 1 when: (1) the country imposes restrictions, such as creditors' consent or minimum dividends to file for reorganization; (2) secured creditors are able to gain possession of their security once the reorganization petition has been approved (no automatic stay); (3) secured creditors are ranked first in the distribution of the proceeds that result from the disposition of the assets of a bankrupt firm; and (4) the debtor does not retain the administration of its property pending the resolution of the reorganization. The index ranges from 0 to 4 . Source: La Porta, Lopez-de-Silanes, Shleifer, and Vishny (1998).

\section{State owned enterprises}

SOEs in the economy index

SOE output / GDP

SOE investment / gross domestic investment

Public sector employment / total employment
An index of the prevalence of State-owned enterprises as a share of the economy (scale from 0 to 10). Higher scores given to countries with less government-owned enterprises which are estimated to produce less of the country's output. As the estimated size and breadth of the SOE sector increases, countries are assigned lower ratings. Computed both for 1975 and as the average of 1975-1995. Source: Economic Freedom of the World, 1975-1995.

SOE value added of all non-financial SOEs as percentage of total GDP of the economy at market prices. SOE value added is estimated as the sales revenue minus the cost of intermediate inputs, or as the sum of operating surplus (balance) and wage payments Average for the period 1978-1981. Source: Bureaucrats in Business, The World Bank (1995).

Investment (fixed capital formation) by all non-financial SOEs as a percentage of total gross domestic investment of the economy. Average for the period 1978-1991. Source: Bureaucrats in Business, The World Bank (1995).

Average of the ratio of public sector employment in general government to total employment for the period 1976-1996. General government employment includes employment in "all government department offices, organizations and other bodies which are agencies or instruments of the central or local authorities whether accounted for or financed in, ordinary or extraordinary budgets or extra-budgetary funds. They are not solely engaged in administration but also in defense and public order, in the promotion of economic growth and in the provision of education, health, cultural and social services." Source: Schiavio-Campo, de Tommaso and Mukherjee (1997).

Financial development

Private credit / GDP

Liquid liabilities / GDP

Commercial bank assets / total bank assets

Claims on the private sector / GDP

Quasi-liquid liabilities / GDP
Value of credits by deposit money banks and other financial institutions to the private sector divided by GDP. It excludes credit issues by the central bank, credit to the public sector and cross-claims of one of the group of intermediaries to another. The variable is constructed following the methodology of Beck, Levine and Loayza (2000) based on data from the International Financial Statistics. Private credit is calculated using lines 22d and 42d, GDP uses line 99b, and CPI comes from line 64 and the monthly statistics from the IFS database. For most countries, the data is available for the period 19601995. Source: International Financial Statistics database and Beck, Levine and Loayza (2000).

Liquid liabilities of the financial system (currency plus demand and interest-bearing liabilities of the banks and non-banks financial intermediaries) divided by GDP. The variable is constructed following the methodology of Beck, Levine and Loayza (2000) based on data from the International Financial Statistics. Liquid liabilities is calculated using line 551 (liquid liabilities) or line 351 (money plus quasi money), if liquid liabilities is not available. If none of these two numbers are available, we use line 25 (time and saving deposits). Data for GDP uses line 99b, and data for CPI comes from line64 and the monthly statistics from the IFS database. For most countries, the data is available for the period 1960-1995. Source: International Financial Statistics database and Beck, Levine and Loayza (2000).

It is the ratio of commercial bank domestic assets divided by commercial banks domestic assets plus central bank domestic assets. The variable is constructed following the methodology of Beck, Levine and Loayza (2000). Based on data from the International Financial Statistics using lines 22a-d for the assets of deposit money banks, and lines 12a-d for the assets of the central bank. For most countries, the data is available for the period 1960-1995. Source: International Financial Statistics database and Beck, Levine Loayza (2000).

Claims on the private sector as a percentage of GDP. Claims on the private sector refers to financial resources provided to the private sector --such as through loans, purchases of nonequity securities, and trade credits and other accounts receivablethat establish a claim for repayment. For a few countries these claims include credit to public enterprises when it is not available separately. Claims on the private sector include gross credit from the financial system to individuals, enterprises, nonfinancial public entities not included under net domestic credit, and financial institutions not included elsewhere. The data comes from line 32d of the International Financial Statistics. For most countries, the data is available for the period 1970-1995. Source: World Development Indicators based on data from the International Financial Statistics.

Quasi-liquid liabilities as a percentage of GDP. Quasi-liquid liabilities are the sum of currency deposits in the central bank (M0), plus time and saving deposits, foreign currency transferable deposits, certificates of deposit, and securities repurchase agreements, plus travelers checks, foreign currency time deposits, commercial paper, and shares of mutual funds or market funds held by residents. They equal the M3 money supply less transferable deposit and electronic currency (M1). For most countries, the data is available for the period 1970-1995. Source: World Development Indicators based on data from the International Financial Statistics. 
Domestic credit provided by banking sector / GDP

Interest rate spread

Private claims-claims of top 20 / GDP
Domestic credit provided by the banking sector as a percentage of GDP. Domestic credit provided by the banking sector includes all credit to various sectors on a gross basis, with the exception of credit to the central government, which is net. The banking sector includes monetary authorities and deposit money banks, as well as other banking institutions where data are available (including institutions that do not accept transferable deposits but do incur such liabilities as time and savings deposits). Examples of other banking institutions are savings and mortgage loan institutions and building and loan associations. Data for domestic credit comes from lines 32an, 32b, 32c, 32d, 32f and 32g of the International Financial Statistics. For most countries, the data is available for the period 1970-1995. Source: World Development Indicators based on data from the International Financial Statistics.

Interest rate charged by banks on loans to prime customers minus the interest rate paid by commercial or similar banks for demand, time or saving deposits. For most countries, the data is available for the period 1970-1995. Source: World Development Indicators.

Total private claims in the country minus the claims of the top 20 firms in each country as a proportion of GNP in the period 1992-1994. Source: World Scope Database (1996) and International Financial Statistics.
Log of inflation

Major government crisis

Coups d'etat

Banking crisis dummy

Bank assets affected by crises

Bank nationalizations in crisis

Bank liquidation in crisi
Logarithm of the geometric average annual growth rate of the implicit price deflator for the time period 1970-1993. Source: World Development Report 1995. revolt aimed at such overthrow. The data covers the 1960s, 1970s, and 1980s. Source: Easterly and Levine (1997).

The number of extraconstitutional or forced changes in the top government elite and/or its effective control of the nation's power structure in a given year. Unsuccessful coups are not counted. The data covers the 1960s, 1970s, and 1980s. Source: Easterly and Levine (1997).

Dummy variable equal to 1 if the country had a banking crisis in the period between 1970 and 1995. Source: data constructed by the authors based on Caprio and Klingeliel (1996). and Klingeliel (1996).

Dummy variable equal to 1 if as a result of the banking crisis in the period between 1970 and 1995 the government nationalized any commercial banks. Source: data constructed by the authors based on Caprio and Klingeliel (1996). authors based on Caprio and Klingeliel (1996).
GDP per capita growth, 1960-1995

GNP per capita growth, 1970-1995

Physical capital per capita growth

Savings / GDP

Productivity growth 1
The annual rate of GDP per capita growth for the period 1960-1995. Because of the short period for which there is data available, the variable is not constructed for those countries in our sample which emerged as a result of a breakup of another country (i.e. Czech Republic, Slovak Republic, Croatia, Slovenia, Russia and Kazakhstan). Source: International Financial Statistics database and Beck, Levine and Loayza (2000).

The annual rate of GNP per capita growth for the period 1970- 1995. Because of the short period for which there is data available, the variable is not constructed for those countries in our sample which emerged as a result of a breakup of another country (i.e. Czech Republic, Slovak Republic, Croatia, Slovenia, Russia and Kazakhstan). Source: World Bank Indicators (1997).

The annual rate of physical capital per capita growth for the period 1960-1995 and the period 1970-1995. Because of the short period for which there is data available, the variable is not constructed for those countries in our sample which emerged as a result of a breakup of another country (i.e. Czech Republic, Slovak Republic, Croatia, Slovenia, Russia and Kazakhstan). The variable is constructed following Beck, Levine and Loayza (2000). Source: International Financial Statistics and Beck, Levine and Loayza (2000).

Index of total gross domestic savings as a percentage of GDP for the period 1960-1992. Gross domestic savings are calculated as the difference between GDP and total consumption. Source: World Tables 1995.

The annual rate of total factor productivity per capita growth. Because of the short period for which there is data available, the variable is not constructed for those countries in our sample which emerged as a result of a breakup of another country (i.e. Czech Republic, Slovak Republic, Croatia, Slovenia, Russia and Kazakhstan). The variable is constructed following Beck, Levine and Loayza (2000). Productivity per capita growth equals the growth of GDP per capita minus 0.3 times the growth of physical capital per capita. Source: International Financial Statistics database and Beck, Levine and Loayza (2000). 
The annual rate of productivity of per capita growth considering human capital accumulation as proposed by Mankiw (1995). Because of the short period for which there is data available, the variable is not constructed for those countries in our sample which emerged as a result of a breakup of another country (i.e. Czech Republic, Slovak Republic, Croatia, Slovenia, Russia and Kazakhstan). The variable is constructed following the methodology suggested in Beck, Levine and Loayza (2000). Productivity per capita growth equals the growth of GDP per capita minus 0.3 times the growth of physical capital per capita, minus 0.5 times the average growth rate in years of schooling. Source: International Financial Statistics database and Beck, Levine and Loayza (2000).

Productivity growth 3

The annual rate of productivity of per capita growth considering human capital accumulation as proposed by Hall and Jones (1998). Because of the short period for which there is data available, the variable is not constructed for those countries in our sample which emerged as a result of a breakup of another country (i.e. Czech Republic, Slovak Republic, Croatia, Slovenia, Russia and Kazakhstan). The variable is constructed following Beck, Levine and Loayza (2000). Productivity per capita growth equals the growth of GDP per capita minus 0.3 times the growth of physical capital per capita, minus 0.7 times the product of the average number of years of schooling and the return to schooling estimated in a Mincerian wage regression (Mince 1974) all divided by 0.7 . Formally, productivity growth $3=[$ GDP per capita growth $-0.3 *$ Physical capital per capita growth $-0.7 *$ (Years of Schooling*the return to schooling)]/0.7. Source: International Financial Statistics and Beck, Levine and Loayza (2000).

Other variables

Legal origin

Identifies the legal origin of the Company Law or Commercial Code of each country. There are five possible origins: (1) English Common Law; (2) French Commercial Code; (3) German Commercial Code; (4) Scandinavian Commercial

Code; (5) Socialist/Communist Laws. Source: La Porta, Lopez-de-Silanes, Shleifer, and Vishny (1998) and (1999). 
Table 2

\section{The prevalence of government ownership of banks}

Panel A of the table shows the data of government ownership of banks for all the 92 countries in the sample. The countries are classified according to the legal origin of their commercial laws. Panel B of the table shows the results of tests of means across legal origins.

Panel A: Means by legal origin

\begin{tabular}{|c|c|c|c|c|c|}
\hline \multirow[b]{2}{*}{ Country } & \multicolumn{5}{|c|}{ Share of the assets of the top 10 banks owned or controlled by the government } \\
\hline & GB & GBBP & GB20 & GB50 & GB90 \\
\hline Australia & 12.33 & 22.97 & 20.99 & 20.99 & \\
\hline Bahrain & 7.34 & 7.34 & 3.40 & 3.40 & 3.40 \\
\hline Bangladesh & 95.00 & 95.00 & 100.00 & 100.00 & 89.79 \\
\hline Canada & 0.00 & 0.00 & 0.00 & 0.00 & 0.00 \\
\hline Cyprus & 0.00 & 0.00 & 0.00 & 0.00 & 0.00 \\
\hline Hong Kong & 0.00 & 0.00 & 0.00 & 0.00 & 0.00 \\
\hline India & 84.94 & 96.60 & 100.00 & 94.61 & 59.61 \\
\hline Ireland & 4.48 & 4.48 & 4.50 & 4.50 & 4.50 \\
\hline Israel & 64.64 & 64.64 & 79.81 & 82.25 & 0.00 \\
\hline Kenya & 29.94 & 66.32 & 48.74 & 22.30 & 8.57 \\
\hline Malaysia & 9.93 & 14.46 & 9.93 & 9.93 & 9.94 \\
\hline New Zealand & 0.00 & 23.45 & 0.00 & 0.00 & 0.00 \\
\hline Nigeria & 9.91 & 94.49 & 13.05 & 7.82 & 7.82 \\
\hline Pakistan & 85.96 & 97.75 & 97.75 & 80.10 & 80.10 \\
\hline Saudi Arabia & 29.10 & 29.10 & 43.30 & 22.14 & 22.14 \\
\hline Singapore & 22.40 & 22.41 & 37.72 & 14.62 & 10.20 \\
\hline South Africa & 0.00 & 0.00 & 0.00 & 0.00 & 0.00 \\
\hline Sri Lanka & 71.39 & 100.00 & 76.29 & 68.64 & 68.64 \\
\hline Tanzania & 94.95 & 99.72 & 95.22 & 95.23 & 93.94 \\
\hline Thailand & 17.09 & 17.09 & 21.78 & 21.78 & 0.00 \\
\hline Trinidad and Tobago & 1.54 & 1.54 & 1.54 & 1.54 & 1.54 \\
\hline United Arab Emirates & 41.93 & 41.93 & 37.08 & 59.11 & 9.81 \\
\hline United Kingdom & 0.00 & 0.00 & 0.00 & 0.00 & 0.00 \\
\hline United States & 0.00 & 0.00 & 0.00 & 0.00 & 0.00 \\
\hline Zimbabwe & 30.04 & 30.04 & 49.69 & 29.75 & 7.05 \\
\hline English origin average & 28.52 & 37.17 & 33.63 & 29.55 & 19.22 \\
\hline Afghanistan & 100.00 & 100.00 & 100.00 & 100.00 & 100.00 \\
\hline Algeria & 99.96 & 99.96 & 99.96 & 99.96 & 99.96 \\
\hline Argentina & 60.50 & 60.50 & 60.50 & 60.50 & 60.50 \\
\hline Belgium & 27.59 & 27.59 & 22.29 & 22.29 & 16.64 \\
\hline Bolivia & 18.48 & 68.48 & 17.70 & 17.70 & 17.70 \\
\hline Brazil & 31.70 & 53.93 & 56.89 & 23.22 & 14.23 \\
\hline Chile & 19.72 & 25.53 & 19.72 & 19.73 & 19.73 \\
\hline Colombia & 53.92 & 75.15 & 52.47 & 52.47 & 52.47 \\
\hline Costa Rica & 90.92 & 90.92 & 90.92 & 90.92 & 90.92 \\
\hline Cote d'Ivoire & 20.60 & 20.60 & 20.46 & 15.96 & 13.56 \\
\hline Dominican Republic & 38.93 & 38.93 & 38.93 & 38.93 & 38.93 \\
\hline Ecuador & 40.61 & 33.78 & 40.61 & 40.61 & 40.61 \\
\hline El Salvador & 26.43 & 100.00 & 39.03 & 39.03 & 13.90 \\
\hline Egypt & 88.62 & 90.89 & 96.02 & 86.32 & 80.87 \\
\hline France & 17.26 & 75.09 & 26.18 & 22.42 & 4.91 \\
\hline Greece & 77.82 & 77.82 & 85.47 & 84.09 & 68.65 \\
\hline Guatemala & 22.20 & 22.20 & 22.20 & 22.19 & 22.19 \\
\hline Honduras & 29.90 & 29.90 & 29.90 & 29.90 & 29.90 \\
\hline Indonesia & 42.90 & 42.90 & 42.90 & 42.90 & 42.90 \\
\hline Iran & 100.00 & 100.00 & 100.00 & 100.00 & 100.00 \\
\hline Iraq & 93.77 & 93.77 & 93.77 & 93.77 & 93.77 \\
\hline Italy & 35.95 & 65.44 & 27.81 & 27.81 & 16.61 \\
\hline Jordan & 26.03 & 26.03 & 28.96 & 28.96 & 21.61 \\
\hline Kuwait & 32.84 & 32.84 & 46.19 & 31.67 & 18.43 \\
\hline Lebanon & 7.18 & 7.18 & 7.40 & 7.40 & 7.40 \\
\hline Lybia & 95.12 & 95.12 & 100.00 & 100.00 & 73.11 \\
\hline
\end{tabular}




\begin{tabular}{|c|c|c|c|c|c|}
\hline \multirow[b]{2}{*}{ Country } & \multicolumn{5}{|c|}{ Share of the assets of the top 10 banks owned or controlled by the government } \\
\hline & GB & GBBP & GB20 & GB50 & GB90 \\
\hline Mexico & 35.62 & 100.00 & 35.62 & 35.62 & 35.62 \\
\hline Morocco & 37.90 & 62.99 & 50.89 & 42.23 & 24.03 \\
\hline Netherlands & 9.20 & 9.20 & 10.30 & 10.30 & 6.67 \\
\hline Nicaragua & 63.36 & 100.00 & 63.36 & 63.36 & 63.36 \\
\hline Oman & 25.84 & 25.84 & 27.27 & 27.27 & 24.16 \\
\hline Panama & 17.08 & 17.08 & 17.08 & 17.08 & 17.08 \\
\hline Paraguay & 48.02 & 48.02 & 48.02 & 48.02 & 48.02 \\
\hline Peru & 26.46 & 42.66 & 23.87 & 23.87 & 23.87 \\
\hline Philippines & 27.23 & 34.41 & 34.41 & 34.42 & 17.69 \\
\hline Portugal & 25.66 & 90.38 & 23.73 & 23.73 & 23.73 \\
\hline Qatar & 33.74 & 33.74 & 58.87 & 8.61 & 8.61 \\
\hline Senegal & 27.98 & 27.98 & 36.68 & 21.86 & 19.73 \\
\hline Spain & 1.98 & 1.98 & 6.83 & 0.00 & 0.00 \\
\hline Syria & 100.00 & 100.00 & 100.00 & 100.00 & 100.00 \\
\hline Tunisia & 37.42 & 40.82 & 82.12 & 36.67 & 2.54 \\
\hline Turkey & 56.46 & 56.46 & 55.90 & 55.90 & 55.90 \\
\hline Uruguay & 68.79 & 68.79 & 68.79 & 68.79 & 68.79 \\
\hline Venezuela & 57.98 & 63.36 & 63.36 & 53.41 & 53.41 \\
\hline French origin average & 45.45 & 56.32 & 49.40 & 44.77 & 39.83 \\
\hline Austria & 50.36 & 63.66 & 70.17 & 70.17 & 0.00 \\
\hline Germany & 36.36 & 36.36 & 37.47 & 37.47 & 29.86 \\
\hline Japan & 0.00 & 0.00 & 0.00 & 0.00 & 0.00 \\
\hline South Korea & 25.41 & 44.70 & 41.56 & 21.64 & 13.16 \\
\hline Switzerland & 13.35 & 13.35 & 14.92 & 14.92 & 10.37 \\
\hline Taiwan & 76.51 & 80.87 & 100.00 & 100.00 & 47.84 \\
\hline German origin average & 33.67 & 39.82 & 44.02 & 40.70 & 16.87 \\
\hline Denmark & 8.87 & 17.37 & 10.60 & 8.87 & 8.87 \\
\hline Finland & 30.65 & 30.65 & 30.65 & 30.65 & 30.65 \\
\hline Iceland & 71.34 & 71.34 & 71.34 & 71.34 & 71.33 \\
\hline Norway & 50.45 & 67.99 & 88.25 & 65.67 & 15.80 \\
\hline Sweden & 23.20 & 27.89 & 29.61 & 29.61 & 12.07 \\
\hline Scandinavian origin average & 36.90 & 43.05 & 46.09 & 41.23 & 27.74 \\
\hline Bulgaria & 85.68 & 100.00 & 92.31 & 92.31 & 72.61 \\
\hline China & 99.45 & 100.00 & 100.00 & 99.07 & 99.07 \\
\hline Croatia & 1.04 & 100.00 & 1.29 & 0.00 & 0.00 \\
\hline Czech Republic & 52.00 & 100.00 & 75.44 & 50.45 & 9.58 \\
\hline Hungary & 36.56 & 100.00 & 82.50 & 14.64 & 0.03 \\
\hline Kazakhstan & 56.13 & 100.00 & 80.72 & 44.76 & 44.76 \\
\hline Poland & 84.29 & 100.00 & 94.16 & 83.19 & 76.13 \\
\hline Romania & 62.68 & 100.00 & 87.77 & 87.77 & 24.61 \\
\hline Russia & 32.98 & 100.00 & 49.90 & 49.90 & 13.18 \\
\hline Slovakia & 73.93 & 100.00 & 89.57 & 82.77 & 57.52 \\
\hline Slovenia & 57.29 & 100.00 & 57.29 & 57.29 & 57.29 \\
\hline Vietnam & 99.06 & 100.00 & 99.06 & 99.06 & 99.06 \\
\hline Socialist origin average & 61.76 & 100.00 & 75.83 & 63.43 & 46.15 \\
\hline Average with socialist & 41.74 & 55.01 & 48.03 & 42.61 & 32.90 \\
\hline \multirow[t]{2}{*}{ Average without socialist } & 38.74 & 48.27 & 43.86 & 39.49 & 30.92 \\
\hline & \multicolumn{5}{|c|}{ Panel B: Test of means (t-statistics) } \\
\hline English vs. French & $-2.20^{b}$ & $-2.24^{b}$ & $-1.94^{c}$ & $-1.89^{c}$ & $-2.65^{a}$ \\
\hline English vs. German & -0.34 & -0.15 & -0.61 & -0.67 & 0.17 \\
\hline English vs. Scandinav. & -0.52 & -0.32 & -0.69 & -0.68 & -0.57 \\
\hline English vs. Socialist & $-2.92^{\mathrm{a}}$ & $-8.05^{\mathrm{a}}$ & $-3.47^{\mathrm{a}}$ & $-2.76^{a}$ & $-2.32^{b}$ \\
\hline French vs. German & 0.94 & 1.22 & 0.40 & 0.30 & 1.76 \\
\hline French vs. Scandinav. & 0.63 & 0.92 & 0.23 & 0.25 & 0.83 \\
\hline French vs. Socialist & $-1.73^{c}$ & $-9.35^{a}$ & $-2.79^{a}$ & $-1.87^{\mathrm{c}}$ & -0.60 \\
\hline German vs. Scandinav. & -0.20 & -0.19 & -0.09 & -0.02 & -0.81 \\
\hline German vs. Socialist & $-1.96^{\mathrm{c}}$ & $-4.87^{\mathrm{a}}$ & $-2.05^{c}$ & -1.32 & $-1.83^{c}$ \\
\hline Scandinav. vs. Socialist & -1.67 & $-5.12^{a}$ & $-1.90^{c}$ & -1.33 & -1.01 \\
\hline
\end{tabular}

$\mathrm{a}=$ Significant at $1 \%$ level; $\mathrm{b}=$ Significant at $5 \%$ level ; $\mathrm{c}=$ Significant at $10 \%$ level 
Table 2B

Development banks and the prevalence of government ownership of banks

Panel A of the table shows the average of government ownership of banks by legal origin. Panel B of the table shows the results of tests of means across legal origins.

Panel A: Means by legal origin

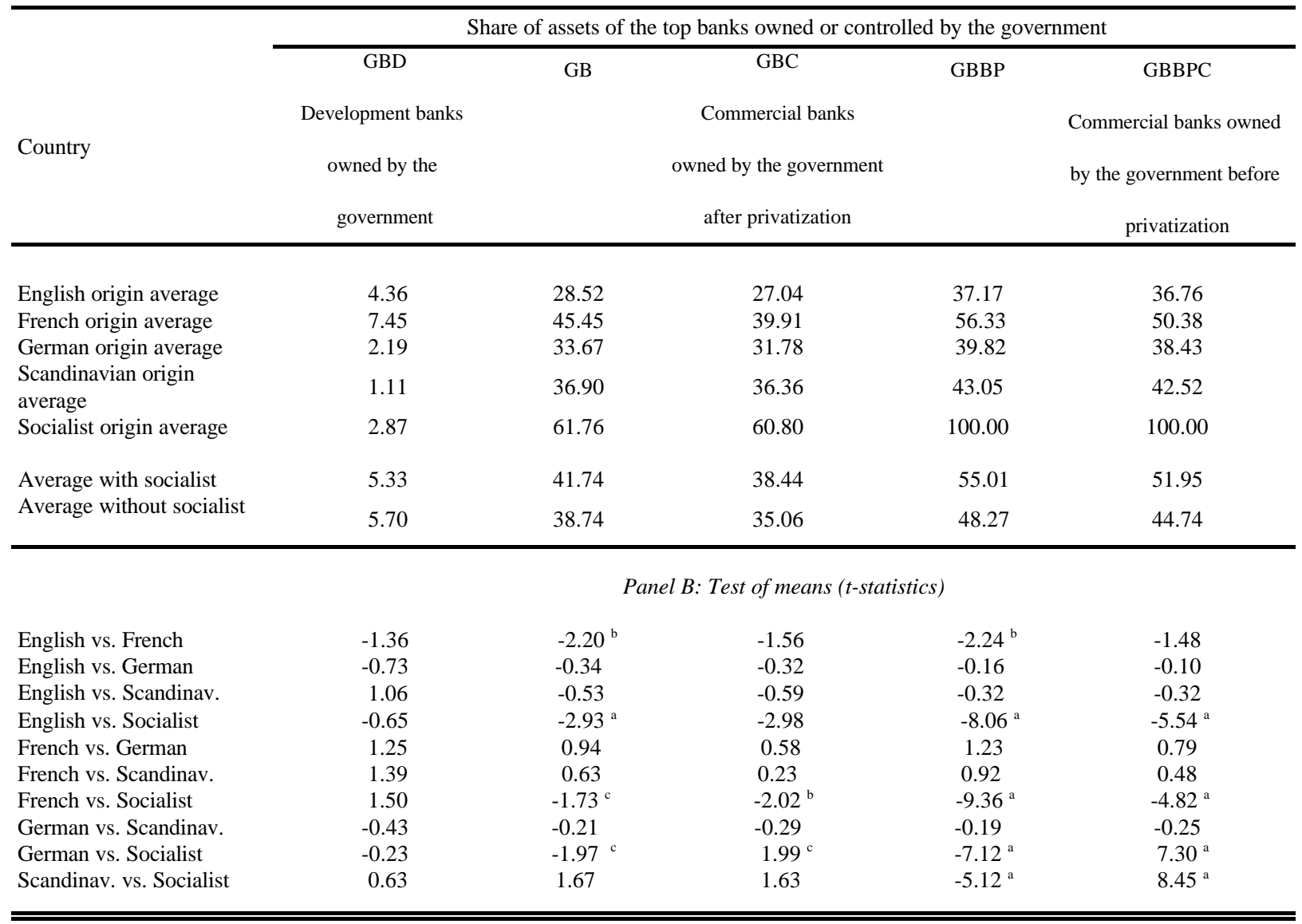

$\mathrm{a}=$ Significant at $1 \%$ level; $\mathrm{b}=$ Significant at $5 \%$ level ; $\mathrm{c}=$ Significant at $10 \%$ level 
Table 3

Which countries have more government ownership of commercial banks?

The first column shows the correlation between each variable and the extent of government ownership of commercial banks in 1995. The second column shows the coefficients and their significance resulting from ordinary least squares regressions of the cross-section of countries. The independent variables are classified into five different groups: (i) initial level of development; (ii) government intervention; (iii)government efficiency; (iv) property rights; (v) state owned enterprises; (vi) initial level of financial development; (vii) crisis and instability. Each regression controls for the log of GDP per capita in 1960. Robust standard errors are shown in parentheses.

\begin{tabular}{|c|c|c|c|}
\hline \multirow[b]{2}{*}{ Independent variables } & \multicolumn{2}{|c|}{ Dependent variable: $G B$} & \multirow[b]{2}{*}{$\begin{array}{l}\text { Number of } \\
\text { observations }\end{array}$} \\
\hline & Raw correlations & Regression coefficients & \\
\hline \multicolumn{4}{|c|}{ Panel A: Initial level of development } \\
\hline Log of GDP per capita in 1960 & $-0.3525^{a}$ & $\begin{array}{l}-0.1119^{\mathrm{a}} \\
(0.0302)\end{array}$ & 91 \\
\hline \multicolumn{4}{|c|}{ Panel B: Government intervention } \\
\hline Business regulation index & $-0.4448^{a}$ & $\begin{array}{l}-0.1279^{\mathrm{a}} \\
(0.0376)\end{array}$ & 87 \\
\hline Frequency of price controls index & $-0.5019^{a}$ & $\begin{array}{l}-0.0563^{\mathrm{a}} \\
(0.0162)\end{array}$ & 74 \\
\hline $\begin{array}{l}\text { Government intervention in the banking } \\
\text { sector }\end{array}$ & $-0.5148^{a}$ & $\begin{array}{l}-0.1558^{a} \\
(0.0273)\end{array}$ & 87 \\
\hline Black market premium 1980s & $0.5205^{\mathrm{a}}$ & $\begin{array}{l}0.2910^{\mathrm{a}} \\
(0.0835)\end{array}$ & 75 \\
\hline Government consumption/GDP & 0.1023 & $\begin{array}{l}-0.2232 \\
(1.2317)\end{array}$ & 87 \\
\hline Transfers and subsidies/GDP & -0.0550 & $\begin{array}{l}0.0111^{\mathrm{b}} \\
(0.0053)\end{array}$ & 70 \\
\hline Political rights index & $-0.3404^{b}$ & $\begin{array}{l}-0.0339^{\mathrm{c}} \\
(0.0170)\end{array}$ & 90 \\
\hline Democracy score & $-0.3566^{\mathrm{b}}$ & $\begin{array}{l}-0.0183^{\mathrm{b}} \\
(0.0087)\end{array}$ & 90 \\
\hline
\end{tabular}

Panel C: Government efficiency

\begin{tabular}{|c|c|c|c|}
\hline Tax compliance & $-0.4880^{\text {a }}$ & $\begin{array}{l}-0.1161^{\mathrm{a}} \\
(0.0358)\end{array}$ & 47 \\
\hline Bureaucratic quality index & $-0.4441^{\mathrm{a}}$ & $\begin{array}{l}-0.0444^{\mathrm{a}} \\
(0.0138)\end{array}$ & 85 \\
\hline Corruption index & $-0.2934^{c}$ & $\begin{array}{l}-0.0172 \\
(0.0176)\end{array}$ & 85 \\
\hline \multicolumn{4}{|c|}{ Panel D: Property rights } \\
\hline Property rights index & $-0.5283^{a}$ & $\begin{array}{l}-0.1397^{\mathrm{a}} \\
(0.0301)\end{array}$ & 89 \\
\hline Rule of law index & $-0.3136^{c}$ & $\begin{array}{l}-0.0338 \\
(0.0261)\end{array}$ & 85 \\
\hline $\begin{array}{l}\text { Government repudiation of contracts } \\
\text { index }\end{array}$ & $-0.4315^{a}$ & $\begin{array}{l}-0.0574^{\mathrm{a}} \\
(0.0180)\end{array}$ & 85 \\
\hline Antidirectors rights index & -0.2570 & $\begin{array}{l}-0.0481^{\mathrm{c}} \\
(0.0258)\end{array}$ & 49 \\
\hline Creditors rights index & -0.1220 & $\begin{array}{l}-0.0062 \\
(0.0255)\end{array}$ & 47 \\
\hline
\end{tabular}

Panel E: State owned enterprises

SOEs in the economy index

SOE output/GDP

SOE investment/gross domestic investment

$\begin{array}{ll}-0.4612^{\mathrm{a}} & -0.0557^{\mathrm{a}} \\ & (0.0123) \\ 0.3511 & 0.0083^{\mathrm{a}} \\ & (0.0027) \\ 0.5491^{\mathrm{a}} & 0.0118^{\mathrm{a}} \\ & (0.0022)\end{array}$

$-0.0557^{\mathrm{a}}$

$0.0083^{\mathrm{a}}$

$0.0118^{\mathrm{a}}$

$(0.0022)$ 


\begin{tabular}{|c|c|c|c|}
\hline \multirow[b]{2}{*}{ Independent variables } & \multicolumn{2}{|c|}{ Dependent variable: $G B$} & \multirow[b]{2}{*}{$\begin{array}{l}\text { Number of } \\
\text { observations }\end{array}$} \\
\hline & Raw correlations & Regression coefficients & \\
\hline SOE employment/employment & 0.2548 & $\begin{array}{r}1.0363^{\mathrm{c}} \\
(0.6080) \\
\end{array}$ & 40 \\
\hline \multicolumn{4}{|c|}{ Panel F: Initial level of financial development } \\
\hline Private credit/GDP in 1960 & -0.2330 & $\begin{array}{l}-0.1751 \\
(0.1520)\end{array}$ & 89 \\
\hline Liquid liabilities/ GDP in 1960 & -0.2468 & $\begin{array}{l}-0.1891^{\mathrm{c}} \\
(0.1093)\end{array}$ & 88 \\
\hline $\begin{array}{l}\text { Commercial bank assets/total bank } \\
\text { assets in } 1960\end{array}$ & -0.2679 & $\begin{array}{l}-0.2154 \\
(0.1726)\end{array}$ & 89 \\
\hline Quasi-liquid liabilities/GDP in 1970 & $-0.3757^{\text {a }}$ & $\begin{array}{l}-0.0041^{\mathrm{a}} \\
(0.0012)\end{array}$ & 87 \\
\hline $\begin{array}{l}\text { Domestic credit by the banking sector } \\
\text { /GDP in } 1970\end{array}$ & -0.1474 & $\begin{array}{l}-0.0007 \\
(0.0012)\end{array}$ & 90 \\
\hline $\begin{array}{l}\text { Claims on the private sector /GDP in } \\
1970\end{array}$ & -0.0969 & $\begin{array}{l}-0.5438^{\mathrm{c}} \\
{[0.3193]}\end{array}$ & 89 \\
\hline \multicolumn{4}{|c|}{ Panel G: Crisis and instability } \\
\hline Log of inflation & 0.2196 & $\begin{array}{l}0.4536^{\mathrm{c}} \\
(0.2708)\end{array}$ & 68 \\
\hline Major government crises & -0.1262 & $\begin{array}{l}-0.0560 \\
(0.0493)\end{array}$ & 75 \\
\hline Number of coups d'etat & 0.0648 & $\begin{array}{l}-0.0082 \\
(0.2875)\end{array}$ & 75 \\
\hline Banking crisis dummy & 0.0533 & $\begin{array}{l}-0.0409 \\
(0.0629)\end{array}$ & 91 \\
\hline Bank assets affected by crises & 0.2031 & $\begin{array}{c}0.2216 \\
(0.1400)\end{array}$ & 69 \\
\hline Bank nationalizations in crisis dummy & -0.0345 & $\begin{array}{l}-0.0514 \\
(0.0999)\end{array}$ & 63 \\
\hline Bank liquidations during crisis dummy & -0.0801 & $\begin{array}{r}-0.1299 \\
(0.0988) \\
\end{array}$ & 62 \\
\hline
\end{tabular}

$\mathrm{a}=$ Significant at $1 \%$ level; $\mathrm{b}=$ Significant at $5 \%$ level; c=Significant at $10 \%$ level. 
Table 4

Government banking and financial development

Ordinary least square (OLS) regressions for the cross-section of countries. The dependent variables are the growth of various financial development measures. All variables are defined in Table 1. Robust standard errors are shown in parenthesis.

\begin{tabular}{|c|c|c|c|c|c|c|}
\hline \multirow[b]{2}{*}{ Independent variables } & \multicolumn{6}{|c|}{ Dependent variables } \\
\hline & $\begin{array}{c}\text { Growth of } \\
\text { private credit / } \\
\text { GDP }\end{array}$ & $\begin{array}{c}\text { Growth of } \\
\text { liquid liabilities } \\
\text { / GDP }\end{array}$ & $\begin{array}{l}\text { Growth of } \\
\text { commercial bank } \\
\text { assets / total bank } \\
\text { assets }\end{array}$ & $\begin{array}{l}\text { Growth of } \\
\text { claims on } \\
\text { private sector } \\
\text { /GDP }\end{array}$ & $\begin{array}{l}\text { Growth of } \\
\text { quasi-liquid } \\
\text { liabilities/ } \\
\text { GDP }\end{array}$ & $\begin{array}{c}\text { Growth of } \\
\text { domestic credit } \\
\text { /GDP }\end{array}$ \\
\hline \multicolumn{7}{|c|}{ Panel A: Annual growth rates 1960-1995 } \\
\hline GBBP & $\begin{array}{l}-0.0939^{c} \\
(0.0475)\end{array}$ & $\begin{array}{l}-0.0136 \\
(0.0197)\end{array}$ & $\begin{array}{l}-0.0099 \\
(0.0075)\end{array}$ & & & \\
\hline Private credit / GDP in 1960 & $\begin{array}{l}-0.0583^{c} \\
(0.0345)\end{array}$ & & & & & \\
\hline Liquid liabilities/GDP in 1960 & & $\begin{array}{l}-0.0895^{c} \\
(0.0451)\end{array}$ & & & & \\
\hline $\begin{array}{l}\text { Commercial bank assets / total bank } \\
\text { assets in } 1960\end{array}$ & & & $\begin{array}{l}-0.0721^{\mathrm{a}} \\
(0.0173)\end{array}$ & & & \\
\hline Log GDP per capita in 1960 & $\begin{array}{c}0.0203 \\
(0.0182)\end{array}$ & $\begin{array}{c}0.0039 \\
(0.0093)\end{array}$ & $\begin{array}{c}0.0024 \\
(0.0026)\end{array}$ & & & \\
\hline Intercept & $\begin{array}{l}-0.0522 \\
(0.1096)\end{array}$ & $\begin{array}{c}0.0402 \\
(0.0551)\end{array}$ & $\begin{array}{l}0.0518^{b} \\
(0.0218)\end{array}$ & & & \\
\hline Number of observations & 89 & 88 & 89 & & & \\
\hline A djusted $R^{2}$ & 0.07 & 0.07 & 0.37 & & & \\
\hline \multicolumn{7}{|c|}{ Panel B: Annual growth rates 1970-1995 } \\
\hline GBBP & $\begin{array}{l}-0.0545^{b} \\
(0.0268)\end{array}$ & $\begin{array}{l}-0.0067 \\
(0.0175)\end{array}$ & $\begin{array}{l}-0.0065 \\
(0.0076)\end{array}$ & $\begin{array}{l}-0.0766^{b} \\
(0.0303)\end{array}$ & $\begin{array}{l}-0.0180^{c} \\
(0.0103)\end{array}$ & $\begin{array}{l}-0.0680^{b} \\
(0.0297)\end{array}$ \\
\hline Private credit / GDP in 1970 & $\begin{array}{l}-0.0386 \\
(0.0232)\end{array}$ & & & & & \\
\hline Liquid liabilities/GDP in 1970 & & $\begin{array}{r}-0.0826^{c} \\
(0.0418)\end{array}$ & & & & \\
\hline $\begin{array}{l}\text { Commercial bank assets / total bank } \\
\text { assets in } 1970\end{array}$ & & & $\begin{array}{l}-0.0490^{c} \\
(0.0259)\end{array}$ & & & \\
\hline $\begin{array}{l}\text { Claims on the private sector / GDP in } \\
1970\end{array}$ & & & & $\begin{array}{l}-0.0007^{b} \\
(0.0303)\end{array}$ & & \\
\hline Quasi liabilities / GDP in 1970 & & & & & $\begin{array}{l}-0.0007^{\mathrm{a}} \\
(0.0001)\end{array}$ & \\
\hline Domestic credit / GDP in 1970 & & & & & & $\begin{array}{l}-0.0009^{a} \\
(0.0003)\end{array}$ \\
\hline Log GDP per capita in 1970 & $\begin{array}{l}0.0149 \\
(0.0128)\end{array}$ & $\begin{array}{l}0.0076 \\
(0.0065)\end{array}$ & $\begin{array}{c}0.0023 \\
(0.0019)\end{array}$ & $\begin{array}{l}-0.0082 \\
(0.0077)\end{array}$ & $\begin{array}{l}-0.0062^{b} \\
(0.0026)\end{array}$ & $\begin{array}{c}0.0045 \\
(0.0065)\end{array}$ \\
\hline Intercept & $\begin{array}{l}-0.0626 \\
(0.1013)\end{array}$ & $\begin{array}{c}0.0161 \\
(0.0489)\end{array}$ & $\begin{array}{c}0.0289 \\
(0.0197)\end{array}$ & $\begin{array}{l}0.1377 \\
(0.0543)\end{array}$ & $\begin{array}{l}0.1041^{a} \\
(0.0220)\end{array}$ & $\begin{array}{l}0.0586 \\
(0.0536)\end{array}$ \\
\hline N umber of observations & 90 & 89 & 89 & 89 & 87 & 90 \\
\hline A djusted $R^{2}$ & 0.07 & 0.19 & 0.11 & 0.14 & 0.29 & 0.24 \\
\hline
\end{tabular}

a= Significant at 1\% level; $\mathrm{b}=$ Significant at $5 \%$ level; $\mathrm{c}=$ Significant at 10\% level. 
Table 5

Simple growth regressions

Ordinary least squares (OLS) regressions of the cross-section of countries. The dependent variables are: (1) The average annual growth rate of GDP per capita for 1960-1995; and (2) the average annual growth rate of GNP per capita for 1970-1995. The independent variables are described in Table 1. Robust standard errors are shown in parenthesis.

\begin{tabular}{|c|c|c|c|c|c|c|c|c|}
\hline \multirow[b]{2}{*}{$\begin{array}{l}\text { Dependent } \\
\text { variables }\end{array}$} & \multicolumn{7}{|c|}{ Independent variables } & \multirow[b]{2}{*}{$\begin{array}{c}\text { Adj. } \mathrm{R}^{2} \\
{[\mathrm{~N}]}\end{array}$} \\
\hline & GBBP & $\begin{array}{l}\text { Initial log of GDP } \\
\text { per capita }\end{array}$ & $\begin{array}{l}\text { Initial private } \\
\text { credit/GDP }\end{array}$ & $\begin{array}{l}\text { Initial liquid- } \\
\text { liabilities/GDP }\end{array}$ & $\begin{array}{c}\text { Initial commercial } \\
\text { bank assets/total bank } \\
\text { assets }\end{array}$ & $\begin{array}{l}\text { Average years of } \\
\text { schooling }\end{array}$ & Intercept & \\
\hline \multicolumn{9}{|c|}{ Panel A: Controls for initial development levels } \\
\hline $\begin{array}{l}\text { GDP per capita } \\
\text { growth 1960-95 }\end{array}$ & $\begin{array}{l}-2.4864^{\mathrm{a}} \\
(0.7630)\end{array}$ & $\begin{array}{l}-0.6924^{b} \\
(0.3107)\end{array}$ & & & & & $\begin{array}{l}7.0599^{\mathrm{a}} \\
(1.9992)\end{array}$ & $\begin{array}{c}0.1370 \\
{[85]}\end{array}$ \\
\hline $\begin{array}{l}\text { GNP per capita } \\
\text { growth } 1970-95\end{array}$ & $\begin{array}{l}-2.5366^{\mathrm{a}} \\
(0.8400)\end{array}$ & $\begin{array}{l}-0.6836^{\mathrm{a}} \\
(0.2080)\end{array}$ & & & & & $\begin{array}{l}7.8414^{\mathrm{a}} \\
(1.9001)\end{array}$ & $\begin{array}{c}0.1475 \\
{[85]}\end{array}$ \\
\hline \multicolumn{9}{|c|}{ Panel B: Controls for initial development levels and average years of schooling } \\
\hline $\begin{array}{l}\text { GDP per capita } \\
\text { growth 1960-95 }\end{array}$ & $\begin{array}{l}-2.2161^{\mathrm{a}} \\
(0.6715)\end{array}$ & $\begin{array}{l}-1.5215^{\mathrm{a}} \\
(0.3283)\end{array}$ & & & & $\begin{array}{l}0.5525^{\mathrm{a}} \\
(0.1267)\end{array}$ & $\begin{array}{l}8.9747^{\mathrm{a}} \\
(1.6568)\end{array}$ & $\begin{array}{c}0.3289 \\
{[85]}\end{array}$ \\
\hline $\begin{array}{l}\text { GNP per capita } \\
\text { growth } 1970-95\end{array}$ & $\begin{array}{l}-2.0236^{\mathrm{a}} \\
(0.6835)\end{array}$ & $\begin{array}{l}-1.0340^{\mathrm{a}} \\
(0.2244)\end{array}$ & & & & $\begin{array}{l}0.4233^{\mathrm{a}} \\
(0.1154)\end{array}$ & $\begin{array}{l}8.0036^{\mathrm{a}} \\
(1.6265)\end{array}$ & $\begin{array}{c}0.2645 \\
{[84]}\end{array}$ \\
\hline \multicolumn{9}{|c|}{ Panel C: Controls for initial development and initial financial development and average levels of schooling } \\
\hline $\begin{array}{l}\text { GDP per capita } \\
\text { growth 1960-95 }\end{array}$ & $\begin{array}{l}-1.8537^{\mathrm{a}} \\
(0.6744)\end{array}$ & $\begin{array}{l}-1.7011^{\mathrm{a}} \\
(0.2890)\end{array}$ & $\begin{array}{l}3.2812^{\mathrm{a}} \\
(1.0478)\end{array}$ & & & $\begin{array}{l}0.5045^{\mathrm{a}} \\
(0.1170)\end{array}$ & $\begin{array}{l}9.2660^{\mathrm{a}} \\
(1.5235)\end{array}$ & $\begin{array}{c}0.4161 \\
{[83]}\end{array}$ \\
\hline $\begin{array}{l}\text { GNP per capita } \\
\text { growth 1970-95 }\end{array}$ & $\begin{array}{l}-1.5099^{\mathrm{b}} \\
(0.6700)\end{array}$ & $\begin{array}{l}-1.1934^{\mathrm{a}} \\
(0.2046)\end{array}$ & $\begin{array}{l}3.7304^{\mathrm{a}} \\
(0.8608)\end{array}$ & & & $\begin{array}{l}0.3543^{\mathrm{a}} \\
(0.1048)\end{array}$ & $\begin{array}{l}8.1922^{\mathrm{a}} \\
(1.4779)\end{array}$ & $\begin{array}{c}0.3718 \\
{[83]}\end{array}$ \\
\hline $\begin{array}{l}\text { GDP per capita } \\
\text { growth } 1960-95\end{array}$ & $\begin{array}{l}-1.7912^{b} \\
(0.7090)\end{array}$ & $\begin{array}{l}-1.5913^{\mathrm{a}} \\
(0.3122)\end{array}$ & & $\begin{array}{l}2.1111^{\mathrm{a}} \\
(0.7992)\end{array}$ & & $\begin{array}{l}0.5127^{\mathrm{a}} \\
(0.1268)\end{array}$ & $\begin{array}{l}8.6833^{\mathrm{a}} \\
(1.6452)\end{array}$ & $\begin{array}{c}0.3772 \\
{[83]}\end{array}$ \\
\hline $\begin{array}{l}\text { GNP per capita } \\
\text { growth 1970-95 }\end{array}$ & $\begin{array}{l}-1.7121^{\mathrm{b}} \\
(0.6699)\end{array}$ & $\begin{array}{l}-1.1418^{a} \\
(0.2154)\end{array}$ & & $\begin{array}{l}3.4698^{\mathrm{a}} \\
(1.0179)\end{array}$ & & $\begin{array}{l}0.3206^{\mathrm{a}} \\
(0.1096)\end{array}$ & $\begin{array}{l}7.9364^{\mathrm{a}} \\
(1.5934)\end{array}$ & $\begin{array}{c}0.3604 \\
{[83]}\end{array}$ \\
\hline $\begin{array}{l}\text { GDP per capita } \\
\text { growth 1960-95 }\end{array}$ & $\begin{array}{c}-2.0317^{\mathrm{a}} \\
0.7560)\end{array}$ & $\begin{array}{l}-1.5312^{\mathrm{a}} \\
(0.3684)\end{array}$ & & & $\begin{array}{c}0.3750 \\
(1.2289)\end{array}$ & $\begin{array}{l}0.5604^{\mathrm{a}} \\
(0.1358)\end{array}$ & $\begin{array}{l}8.5987^{\mathrm{a}} \\
(1.7732)\end{array}$ & $\begin{array}{c}0.3097 \\
{[83]}\end{array}$ \\
\hline $\begin{array}{l}\text { GNP per capita } \\
\text { growth } 1970-95\end{array}$ & $\begin{array}{l}-1.5459^{b} \\
(0.7398)\end{array}$ & $\begin{array}{l}-1.1397^{\mathrm{a}} \\
(0.2581)\end{array}$ & & & $\begin{array}{l}2.0754 \\
(1.5696)\end{array}$ & $\begin{array}{l}0.4463^{\mathrm{a}} \\
(0.1240)\end{array}$ & $\begin{array}{l}6.7457^{\mathrm{a}} \\
(1.6271)\end{array}$ & $\begin{array}{c}0.2684 \\
{[82]}\end{array}$ \\
\hline
\end{tabular}

a=Significant at $1 \%$ level; b=Significant at $5 \%$ level; c=Significant at $10 \%$ level. 
Table 6

Growth results with different combination of controls

Ordinary Least Square regressions of the cross-section of countries. The dependent variable is the average growth rate of GDP per capita for the period from 1960 to 1995. The independent variables are defined in Table 1. The regional dummies are for Africa, North America, South America, Europe, Oceania, Middle East and the rest of Asia. Robust standard errors are shown in parenthesis.

\begin{tabular}{|c|c|c|c|c|c|c|c|c|}
\hline \multirow{2}{*}{$\begin{array}{l}\text { Independent variables: } \\
\text { GBBP }\end{array}$} & \multicolumn{8}{|c|}{ Dependent variable: Growth rate of GDP per capita 1960-1995 } \\
\hline & $\begin{array}{l}-1.7455^{\mathrm{b}} \\
(0.7393)\end{array}$ & $\begin{array}{r}-2.0481^{\mathrm{a}} \\
(0.7562)\end{array}$ & $\begin{array}{l}-1.2338 \\
(1.0179)\end{array}$ & $\begin{array}{r}-1.6296^{\mathrm{b}} \\
(0.7960)\end{array}$ & $\begin{array}{l}-1.7976^{\mathrm{c}} \\
(1.0016)\end{array}$ & $\begin{array}{l}-1.3277^{\mathrm{c}} \\
(0.6830)\end{array}$ & $\begin{array}{l}-1.5225^{\mathrm{a}} \\
(0.5487)\end{array}$ & $\begin{array}{l}-1.3281^{\mathrm{b}} \\
(0.6185)\end{array}$ \\
\hline $\begin{array}{l}\text { High inflation dummy 1970- } \\
1995\end{array}$ & $\begin{array}{l}-0.7923 \\
(0.6129)\end{array}$ & & & & & & & \\
\hline Black market premium 1960s & & $\begin{array}{l}-0.3102 \\
(0.5575)\end{array}$ & & & & & & \\
\hline $\begin{array}{l}\text { Index of government } \\
\text { intervention in the economy } \\
1975\end{array}$ & & & $\begin{array}{l}-0.1973 \\
(0.2136)\end{array}$ & & & & & \\
\hline Top marginal tax rate 1975 & & & & $\begin{array}{c}0.0205 \\
(0.0194)\end{array}$ & & & & \\
\hline $\begin{array}{l}\text { Transfers and subsidies /GDP } \\
1975\end{array}$ & & & & & $\begin{array}{l}-0.0654 \\
(0.1459)\end{array}$ & & & \\
\hline $\begin{array}{l}\text { SOE in the economy index } \\
1975\end{array}$ & & & & & & $\begin{array}{c}0.0298 \\
(0.1025)\end{array}$ & & \\
\hline SOE output / GDP 1978-91 & & & & & & & $\begin{array}{c}0.0412 \\
(0.0275)\end{array}$ & \\
\hline Index of Liberty 1980 s & & & & & & & & $\begin{array}{l}-0.0195^{b} \\
(0.0088)\end{array}$ \\
\hline Latitude & $\begin{array}{l}-0.7293 \\
(1.9165)\end{array}$ & $\begin{array}{l}-0.4757 \\
(1.9844)\end{array}$ & $\begin{array}{l}-0.6414 \\
(2.1916)\end{array}$ & $\begin{array}{l}-0.7564 \\
(2.3257)\end{array}$ & $\begin{array}{l}-1.0889 \\
(2.7995)\end{array}$ & $\begin{array}{c}0.4568 \\
(1.7836)\end{array}$ & $\begin{array}{c}1.2722 \\
(1.8387)\end{array}$ & $\begin{array}{c}0.1754 \\
(1.9102)\end{array}$ \\
\hline Log of GDP per capita in 1960 & $\begin{array}{l}-1.6217^{\mathrm{a}} \\
(0.4041)\end{array}$ & $\begin{array}{l}-1.5173^{\mathrm{a}} \\
(0.5070)\end{array}$ & $\begin{array}{l}-0.6192 \\
(0.5400)\end{array}$ & $\begin{array}{r}-0.9503^{\mathrm{c}} \\
(0.4910)\end{array}$ & $\begin{array}{l}-0.9439 \\
(0.6659)\end{array}$ & $\begin{array}{l}-0.6374 \\
(0.4412)\end{array}$ & $\begin{array}{l}-1.3635^{\mathrm{a}} \\
(0.4887)\end{array}$ & $\begin{array}{l}-1.7058^{\mathrm{a}} \\
(0.4315)\end{array}$ \\
\hline Private credit/GDP in 1960 & $\begin{array}{l}2.2747^{\mathrm{b}} \\
(1.0467)\end{array}$ & $\begin{array}{l}2.1311^{\mathrm{c}} \\
(1.1331)\end{array}$ & $\begin{array}{l}1.9111 \\
(1.2526)\end{array}$ & $\begin{array}{l}1.7097^{\mathrm{c}} \\
(1.0190)\end{array}$ & $\begin{array}{l}1.5986 \\
(1.0547)\end{array}$ & $\begin{array}{l}1.1409 \\
(0.9616)\end{array}$ & $\begin{array}{l}3.2083^{\mathrm{b}} \\
(1.5475)\end{array}$ & $\begin{array}{l}1.9837^{\mathrm{c}} \\
(1.1582)\end{array}$ \\
\hline Average schooling & $\begin{array}{l}0.4204^{\mathrm{a}} \\
(0.1531)\end{array}$ & $\begin{array}{l}0.3320^{\mathrm{b}} \\
(0.1525)\end{array}$ & $\begin{array}{c}0.1563 \\
(0.1632)\end{array}$ & $\begin{array}{l}0.2122 \\
10.1528\end{array}$ & $\begin{array}{c}0.1514 \\
(0.1692)\end{array}$ & $\begin{array}{l}0.2030 \\
(0.1359)\end{array}$ & $\begin{array}{l}0.2018 \\
(0.1247)\end{array}$ & $\begin{array}{l}0.3465^{b} \\
(0.1527)\end{array}$ \\
\hline Intercept & $\begin{array}{l}10.6535^{a} \\
(1.9631)\end{array}$ & $\begin{array}{l}10.6179^{a} \\
(2.4802)\end{array}$ & $\begin{array}{l}8.1367^{b} \\
(3.3687)\end{array}$ & $\begin{array}{c}7.5708^{\mathrm{a}} \\
(2.2157)\end{array}$ & $\begin{array}{l}9.1128^{b} \\
(3.9865)\end{array}$ & $\begin{array}{l}6.4360^{a} \\
(2.0940)\end{array}$ & $\begin{array}{l}8.9837^{\mathrm{a}} \\
(2.0698)\end{array}$ & $\begin{array}{l}12.4030^{\mathrm{a}} \\
(2.3616)\end{array}$ \\
\hline Regional dummies & Y es & Y es & Y es & Y es & Yes & Y es & Yes & Yes \\
\hline Number of observations & 83 & 82 & 52 & 54 & 52 & 73 & 49 & 81 \\
\hline A djusted $R^{2}$ & 0.5190 & 0.4764 & 0.5475 & 0.5875 & 0.5620 & 0.4450 & 0.5462 & 0.5418 \\
\hline
\end{tabular}

$\mathrm{a}=$ Significant at $1 \%$ level; $\mathrm{b}=$ Significant at $5 \%$ level; $\mathrm{c}=$ Significant at $10 \%$ level. 
Table 7

Capital accumulation, productivity growth and government ownership of banks

Ordinary least square (OLS) regressions for the cross-section of countries. The dependent variables are: (1) the annual growth rate of physical capital per capita for the period 1960-1992; (2) the average of the savings to GDP ratio for the period 1960-1993; (3) the annual productivity per capita growth rate for the period 1960-1995 (Productivity growth 1); (4) the annual productivity per capita growth rate considering human capital accumulation, following Mankiw (1995) for the period 1960-1995 (Productivity growth 2); and (5) the annual productivity per capital growth rate considering human capital accumulation, following Hall and Jones (1998), for the period 1960-1995 (Productivity growth 3). The independent variables are defined in Table 1. Robust standard errors are shown in parenthesis.

\begin{tabular}{|c|c|c|c|c|c|c|}
\hline \multirow[b]{2}{*}{ Dependent variables } & \multicolumn{5}{|c|}{ Independent variables } & \multirow[b]{2}{*}{$\begin{array}{l}\text { Adj. } \mathrm{R}^{2} \\
{[\mathrm{~N}]}\end{array}$} \\
\hline & GBBP & $\begin{array}{l}\text { Log of GDP per } \\
\text { capita in } 1960\end{array}$ & $\begin{array}{l}\text { Private credit / } \\
\text { GDP in } 1960\end{array}$ & $\begin{array}{l}\text { Average years of } \\
\text { schooling, }\end{array}$ & Intercept & \\
\hline \multicolumn{7}{|c|}{ Panel A: Capital accumulation and savings rate } \\
\hline $\begin{array}{l}\text { Physical capital per capita } \\
\text { growth } 0.5260\end{array}$ & $\begin{array}{l}-0.5262 \\
(0.9277)\end{array}$ & $\begin{array}{l}-0.3814 \\
(0.3454)\end{array}$ & & & $\begin{array}{l}5.6024^{b} \\
(2.4188)\end{array}$ & $\begin{array}{c}0.0173 \\
{[77]}\end{array}$ \\
\hline Savings / GDP & $\begin{array}{l}0.0360 \\
(0.0278)\end{array}$ & $\begin{array}{l}0.0383^{\mathrm{a}} \\
(0.0130)\end{array}$ & & & $\begin{array}{c}0.0011 \\
(0.0831)\end{array}$ & $\begin{array}{c}0.1895 \\
{[76]}\end{array}$ \\
\hline $\begin{array}{l}\text { Physical capital per capita } \\
\text { growth }\end{array}$ & $\begin{array}{c}0.1223 \\
(0.9169)\end{array}$ & $\begin{array}{l}-1.3036^{\mathrm{a}} \\
(0.4211)\end{array}$ & $\begin{array}{l}3.0902^{\mathrm{b}} \\
(1.1795)\end{array}$ & $\begin{array}{l}0.3920^{\mathrm{b}} \\
(0.1569)\end{array}$ & $\begin{array}{l}7.9165^{\mathrm{a}} \\
(2.2806)\end{array}$ & $\begin{array}{c}0.1561 \\
{[77]}\end{array}$ \\
\hline Savings / GDP & $\begin{array}{c}0.0303 \\
(0.0286)\end{array}$ & $\begin{array}{l}0.0449^{\mathrm{c}} \\
(0.0231)\end{array}$ & $\begin{array}{c}0.0383 \\
(0.0612)\end{array}$ & $\begin{array}{l}-0.0069 \\
(0.0062)\end{array}$ & $\begin{array}{l}-0.0103 \\
(0.1074)\end{array}$ & $\begin{array}{c}0.2122 \\
{[75]}\end{array}$ \\
\hline \multicolumn{7}{|c|}{ Panel B: Productivity growth } \\
\hline Productivity growth 1 & $\begin{array}{l}-1.4555^{b} \\
(0.5785)\end{array}$ & $\begin{array}{l}-0.2745 \\
(0.2118)\end{array}$ & & & $\begin{array}{l}3.3554^{b} \\
(1.3801)\end{array}$ & $\begin{array}{c}0.0994 \\
{[77]}\end{array}$ \\
\hline Productivity growth 2 & $\begin{array}{l}-1.8944^{\mathrm{a}} \\
(0.6990)\end{array}$ & $\begin{array}{l}-0.1292 \\
(0.3282)\end{array}$ & & & $\begin{array}{c}1.7094 \\
(2.0459)\end{array}$ & $\begin{array}{c}0.1155 \\
{[77]}\end{array}$ \\
\hline Productivity growth 3 & $\begin{array}{l}-1.7174^{c} \\
(0.9335)\end{array}$ & $\begin{array}{l}-0.2450 \\
(0.2224)\end{array}$ & & & $\begin{array}{l}3.2708^{b} \\
(1.5862)\end{array}$ & $\begin{array}{c}0.0792 \\
{[61]}\end{array}$ \\
\hline Productivity growth 1 & $\begin{array}{l}-0.9827^{b} \\
(0.4615)\end{array}$ & $\begin{array}{l}-0.9600^{\mathrm{a}} \\
(0.1993)\end{array}$ & $\begin{array}{l}2.1721^{\mathrm{a}} \\
(0.7305)\end{array}$ & $\begin{array}{l}0.2979^{\mathrm{a}} \\
(0.0784)\end{array}$ & $\begin{array}{l}5.0781^{a} \\
(0.9980)\end{array}$ & $\begin{array}{c}0.3345 \\
{[77]}\end{array}$ \\
\hline Productivity growth 2 & $\begin{array}{c}-1.25791^{\mathrm{b}} \\
(0.4978)\end{array}$ & $\begin{array}{l}-1.1744^{\mathrm{a}} \\
(0.3067)\end{array}$ & $\begin{array}{l}2.1538^{b} \\
(0.8421)\end{array}$ & $\begin{array}{l}0.5150^{\mathrm{a}} \\
(0.0981)\end{array}$ & $\begin{array}{l}4.3608^{a} \\
(1.4231)\end{array}$ & $\begin{array}{c}0.4565 \\
{[77]}\end{array}$ \\
\hline Productivity growth 3 & $\begin{array}{l}-1.1047 \\
(0.7857)\end{array}$ & $\begin{array}{c}-1.1912^{\mathrm{a}} \\
(0.3018)\end{array}$ & $\begin{array}{l}2.7327^{\mathrm{a}} \\
(0.9651)\end{array}$ & $\begin{array}{l}0.3421^{a} \\
(0.1271)\end{array}$ & $\begin{array}{l}5.9653^{\mathrm{a}} \\
(1.4725)\end{array}$ & $\begin{array}{c}0.2637 \\
{[61]}\end{array}$ \\
\hline
\end{tabular}

a=Significant at $1 \%$ level; b=Significant at 5\% level; c=Significant at $10 \%$ level. 
Ordinary least squares regressions for the cross-section of countries. The exact definitions of all variables can be found in Table 1. The dependent variables are measured for 1995 or the most recent period for which information is available. Robust standard errors are shown in parenthesis.

\begin{tabular}{lccccc}
\hline \hline & \multicolumn{4}{c}{ Independent variables } \\
\cline { 2 - 5 } Dependent variables: & GBBP & $\begin{array}{c}\text { Log GDP per } \\
\text { capita in 1960 }\end{array}$ & $\begin{array}{c}\text { Private credit/GDP } \\
\text { in 1960 }\end{array}$ & Intercept & $\begin{array}{c}\text { Adjusted R2 } \\
{[N]}\end{array}$ \\
\hline Private claims-claims of top 20/ & $-0.3445 \mathrm{~b}$ & -0.0181 & $0.6189 \mathrm{c}$ & $0.6091 \mathrm{c}$ & 0.3734 \\
GDP & $(0.1553)$ & $(0.0583)$ & $(0.2938)$ & $(0.3413)$ & {$[32]$} \\
Interest rate spread & $24.3407 \mathrm{a}$ & 4.2412 & $-27.8036 \mathrm{c}$ & -8.8076 & 0.1716 \\
& $(8.3999)$ & $(4.1960)$ & $(14.6115)$ & $(22.6723)$ & {$[58]$} \\
\hline
\end{tabular}

$\mathrm{a}=$ Significant at $1 \%$ level; $\mathrm{b}=$ Significant at $5 \%$ level; $\mathrm{c}=$ Significant at $10 \%$ level. 
Table 9

Instrumental variables: growth, capital accumulation and productivity growth

Instrumental variables (IV) regressions for the cross-section of countries in the sample. The first stage dependent variable is "Government ownership in banks before privatization (GBBP)." This variable is instrumented by dummy variables that reflect the legal origin of the country (Common law, French civil law, German civil law, Scandinavian civil law, and Socialist legal origin) and by variables that capture the percentage of the population in each country that belong to the largest religions in the world (protestant, catholic, muslim and the remaining religions grouped together). The second stage dependent variables are: (1) GDP per capita growth rate for 1960-1995; (2) GNP per capita growth rate for 1970-1995; (3) Physical capital per capita growth rate 1960-1995; (4) savings to GDP ratio for 1960-1992; (5) Productivity per capita growth rate 1 for 1960-1995; (6) Productivity per capita growth rate 2 for 1960-1995; and (7) Productivity per capita growth rate 3 for 1960-1995. Standard errors are shown in parenthesis. The last column shows the $\chi 2$ results for a Hausman (1978) Lagrange Multiplier test. The null hypothesis is that the instruments used are not correlated with the residuals. Critical values of $\chi 2$ for the L-M test ( 8 d.f.) are: $5 \%=15.5073 ; 1 \%=20.0902$.

\begin{tabular}{|c|c|c|c|c|c|c|c|}
\hline \multirow[b]{2}{*}{ Dependent variables } & \multicolumn{5}{|c|}{ Independent variables } & \multirow[b]{2}{*}{$\mathrm{N}$} & \multirow[b]{2}{*}{ LM-test $\chi^{2}$} \\
\hline & GBBP & $\underset{\text { capita }}{\log \text { GDP per }}$ & $\begin{array}{l}\text { Initial private } \\
\text { credit/GDP }\end{array}$ & $\begin{array}{l}\text { Average years } \\
\text { of schooling }\end{array}$ & Intercept & & \\
\hline \multicolumn{8}{|c|}{ Panel A: Economic growth } \\
\hline $\begin{array}{l}\text { GDP per capita growth } \\
1960-95\end{array}$ & $\begin{array}{l}-4.7767 \mathrm{c} \\
(2.7001)\end{array}$ & $\begin{array}{l}-1.3253 \mathrm{a} \\
(0.4263)\end{array}$ & $\begin{array}{l}3.5597 \mathrm{a} \\
(1.2955)\end{array}$ & & $\begin{array}{l}11.0117 \mathrm{a} \\
(3.7746)\end{array}$ & 83 & 1.03 \\
\hline $\begin{array}{l}\text { GDP per capita growth } \\
1960-95\end{array}$ & $\begin{array}{l}-2.6679 \\
(2.3210)\end{array}$ & $\begin{array}{c}-1.7822 \mathrm{a} \\
(0.3614)\end{array}$ & $\begin{array}{l}3.1362 \mathrm{a} \\
(1.0822)\end{array}$ & $\begin{array}{l}0.4912 \mathrm{a} \\
(0.1197)\end{array}$ & $\begin{array}{c}10.2591 \mathrm{a} \\
(3.1266)\end{array}$ & 83 & 0.13 \\
\hline $\begin{array}{l}\text { GNP per capita growth } \\
1970-95\end{array}$ & $\begin{array}{l}-3.5565 \mathrm{~b} \\
(1.5208)\end{array}$ & $\begin{array}{c}-1.0726 \mathrm{a} \\
(0.2355)\end{array}$ & $\begin{array}{l}4.0194 \mathrm{a} \\
(1.2164)\end{array}$ & & $\begin{array}{c}10.1195 \mathrm{a} \\
(2.3326)\end{array}$ & 84 & 1.74 \\
\hline $\begin{array}{l}\text { GNP per capita growth } \\
1970-95\end{array}$ & $\begin{array}{l}-2.3190 \mathrm{c} \\
(1.3195)\end{array}$ & $\begin{array}{c}-1.2506 \mathrm{a} \\
(0.2231)\end{array}$ & $\begin{array}{l}3.5137 \mathrm{a} \\
(1.0708)\end{array}$ & $\begin{array}{l}0.3520 \mathrm{a} \\
(0.1084)\end{array}$ & $\begin{array}{l}9.0508 \mathrm{a} \\
(1.9431)\end{array}$ & 83 & 0.52 \\
\hline \multicolumn{8}{|c|}{ Panel B: Capital accumulation } \\
\hline $\begin{array}{l}\text { Physical capital per capita } \\
\text { growth }\end{array}$ & $\begin{array}{l}-2.7635 \\
(2.4158)\end{array}$ & $\begin{array}{l}-0.9615 \mathrm{~b} \\
(0.4374)\end{array}$ & $\begin{array}{l}2.7123 \\
(1.6630)\end{array}$ & & $\begin{array}{l}9.4219 \mathrm{a} \\
(3.4730)\end{array}$ & 77 & 1.37 \\
\hline $\begin{array}{l}\text { Physical capital per capita } \\
\text { growth }\end{array}$ & $\begin{array}{l}-1.5536 \\
(2.2312)\end{array}$ & $\begin{array}{l}-1.4265 \mathrm{a} \\
(0.4580)\end{array}$ & $\begin{array}{l}2.6641 \mathrm{c} \\
(1.5513)\end{array}$ & $\begin{array}{l}0.3582 \mathrm{~b} \\
(0.1686)\end{array}$ & $\begin{array}{l}9.7417 \mathrm{a} \\
(3.1503)\end{array}$ & 77 & 0.55 \\
\hline Savings/GDP & $\begin{array}{c}0.0386 \\
(0.0560)\end{array}$ & $\begin{array}{l}0.0357 \mathrm{a} \\
(0.0121)\end{array}$ & $\begin{array}{c}0.0273 \\
(0.0539)\end{array}$ & & $\begin{array}{l}0.0072 \mathrm{c} \\
(0.0874)\end{array}$ & 75 & 0.02 \\
\hline Savings/GDP & $\begin{array}{c}0.0445 \\
(0.0548)\end{array}$ & $\begin{array}{l}0.0464 \mathrm{a} \\
(0.0135)\end{array}$ & $\begin{array}{c}0.0391 \\
(0.0540)\end{array}$ & $\begin{array}{l}-0.0068 \\
(0.0047)\end{array}$ & $\begin{array}{l}-0.0269 \\
(0.0867)\end{array}$ & 75 & 0.09 \\
\hline \multicolumn{8}{|c|}{ Panel C: Productivity growth } \\
\hline Productivity growth 1 & $\begin{array}{l}-4.6758 \mathrm{~b} \\
(2.2642)\end{array}$ & $\begin{array}{l}-0.8601 \mathrm{~b} \\
(0.3331)\end{array}$ & $\begin{array}{c}1.4714 \\
(1.1690)\end{array}$ & & $\begin{array}{l}8.0041 \mathrm{a} \\
(2.9738)\end{array}$ & 77 & 2.54 \\
\hline Productivity growth 1 & $\begin{array}{l}-3.1972 \mathrm{c} \\
(1.9477)\end{array}$ & $\begin{array}{l}-1.1224 \mathrm{a} \\
(0.2803)\end{array}$ & $\begin{array}{l}1.6091 \mathrm{a} \\
(0.9528)\end{array}$ & $\begin{array}{l}0.2533 \mathrm{~b} \\
(0.0997)\end{array}$ & $\begin{array}{l}7.4898 \mathrm{a} \\
(2.4036)\end{array}$ & 77 & 1.21 \\
\hline Productivity growth 2 & $\begin{array}{c}-6.6686 \mathrm{~b} \\
(2.9877)\end{array}$ & $\begin{array}{c}-0.8981 \mathrm{~b} \\
(0.4395)\end{array}$ & $\begin{array}{c}1.2107 \\
(1.5425)\end{array}$ & & $\begin{array}{l}8.2628 \text { b } \\
(3.9243)\end{array}$ & 77 & 2.99 \\
\hline Productivity growth 2 & $\begin{array}{l}-3.8673 \mathrm{c} \\
(2.1795)\end{array}$ & $\begin{array}{c}-1.3658 \mathrm{a} \\
(0.3137)\end{array}$ & $\begin{array}{c}1.4903 \\
(1.0662)\end{array}$ & $\begin{array}{l}0.4623 \mathrm{a} \\
(0.1115)\end{array}$ & $\begin{array}{l}7.2026 \mathrm{c} \\
(2.6896)\end{array}$ & 77 & 1.48 \\
\hline Productivity growth 3 & $\begin{array}{c}-7.2304 \mathrm{~b} \\
(3.2640)\end{array}$ & $\begin{array}{c}-1.2660 \mathrm{~b} \\
(0.5576)\end{array}$ & $\begin{array}{c}1.6534 \\
(1.6648)\end{array}$ & & $\begin{array}{l}11.3520 \\
(4.5287)\end{array}$ & 61 & 3.40 \\
\hline Productivity growth 3 & $\begin{array}{c}-5.3889 \mathrm{c} \\
(3.0233)\end{array}$ & $\begin{array}{c}-1.4139 \\
(0.4938)\end{array}$ & $\begin{array}{c}1.9375 \\
(1.4154)\end{array}$ & $\begin{array}{c}0.1923 \\
(0.1992)\end{array}$ & $\begin{array}{c}10.2637 \mathrm{a} \\
(3.7038)\end{array}$ & 61 & 2.23 \\
\hline
\end{tabular}

$\mathrm{a}=$ Significant at $1 \%$ level; $\mathrm{b}=$ Significant at $5 \%$ level; c=Significant at $10 \%$ level. 
Table 10

Growth by groups of countries

Ordinary least square regressions (OLS) of different groups of countries classified according to country characteristics. The dependent variable in all regressions shown is the average annual growth of GDP per capita for the period 1960-1995. The independent variables are described in Table 1. The table has three panels corresponding to different classifications of the countries in the sample. Panel A divides the sample in those countries with initial GDP per capita in 1960 below the median and those above the median. Panel B divides the sample in those countries with initial level of financial development below and those above the median as measured by private credit as a proportion of GDP in 1960. Panel C divides the sample in those countries with property rights in the 1990s below the median and those above the median value for the sample.

\begin{tabular}{|c|c|c|c|c|c|c|}
\hline \multirow[b]{2}{*}{$\begin{array}{l}\text { Dependent variable: } \\
\text { growth rate of GDP per capita 1960-95 }\end{array}$} & \multicolumn{5}{|c|}{ Independent variables: } & \multirow[b]{2}{*}{$\begin{array}{l}\text { Adj. R2 } \\
{[\mathrm{N}]}\end{array}$} \\
\hline & GBBP & $\begin{array}{l}\text { Log GDP per } \\
\text { capita } 1960\end{array}$ & $\begin{array}{l}\text { Initial private } \\
\text { credit/GDP }\end{array}$ & $\begin{array}{l}\text { Average years } \\
\text { of schooling }\end{array}$ & Intercept & \\
\hline \multicolumn{7}{|c|}{ Panel A: Countries ranked by initial level of economic development } \\
\hline $\begin{array}{l}\text { Countries with Log GDP per capita in } \\
1960<\text { median }\end{array}$ & $\begin{array}{l}-2.2328 \mathrm{c} \\
(1.2553)\end{array}$ & $\begin{array}{l}-2.5290 \mathrm{a} \\
(0.8146)\end{array}$ & $\begin{array}{l}3.5590 \mathrm{c} \\
(1.7563)\end{array}$ & $\begin{array}{l}0.6290 \mathrm{c} \\
(0.3039)\end{array}$ & $\begin{array}{c}13.0490 \mathrm{a} \\
(4.5905)\end{array}$ & $\begin{array}{c}0.4399 \\
{[42]}\end{array}$ \\
\hline $\begin{array}{l}\text { Countries with Log GDP per capita in } \\
1960>\text { median }\end{array}$ & $\begin{array}{l}-1.2970 \mathrm{c} \\
(0.7140)\end{array}$ & $\begin{array}{c}-1.8264 \mathrm{a} \\
(0.4485)\end{array}$ & $\begin{array}{l}3.0321 \mathrm{c} \\
(1.4800)\end{array}$ & $\begin{array}{l}0.2933 \mathrm{~b} \\
(0.1201)\end{array}$ & $\begin{array}{c}11.5750 \\
\mathrm{a}\end{array}$ & $\begin{array}{c}0.4884 \\
{[41]}\end{array}$ \\
\hline \multicolumn{7}{|c|}{ Panel B: Countries ranked by initial level of financial development } \\
\hline $\begin{array}{l}\text { Countries with private credit/GDP per } \\
\text { Capital in } 1996<\text { median }\end{array}$ & $\begin{array}{l}-3.4856 \mathrm{a} \\
(0.9432)\end{array}$ & $\begin{array}{c}-2.0369 \mathrm{a} \\
(0.3486)\end{array}$ & $\begin{array}{l}-6.6106 \\
(7.0263)\end{array}$ & $\begin{array}{l}0.7470 \mathrm{a} \\
(0.1742)\end{array}$ & $\begin{array}{l}11.7581 \mathrm{a} \\
(1.8327)\end{array}$ & $\begin{array}{c}0.5771 \\
{[41]}\end{array}$ \\
\hline $\begin{array}{l}\text { Countries with private credit/GDP per } \\
\text { Capital in } 1996>\text { median }\end{array}$ & $\begin{array}{l}-1.4294 \\
(0.9430)\end{array}$ & $\begin{array}{l}-1.1717 \mathrm{~b} \\
(0.4560)\end{array}$ & $\begin{array}{l}2.4402 \mathrm{~b} \\
(1.1115)\end{array}$ & $\begin{array}{c}0.2125 \\
(0.1411)\end{array}$ & $\begin{array}{l}8.1512 \mathrm{a} \\
(2.7431)\end{array}$ & $\begin{array}{c}0.2706 \\
{[42]}\end{array}$ \\
\hline \multicolumn{7}{|c|}{ Panel C: Countries ranked by property rights index of the $1990 \mathrm{~s}$} \\
\hline $\begin{array}{l}\text { Countries with property rights index < } \\
\text { median }\end{array}$ & $\begin{array}{l}-2.6439 \mathrm{~b} \\
(1.0577)\end{array}$ & $\begin{array}{c}-2.4088 \mathrm{a} \\
(0.6468)\end{array}$ & $\begin{array}{l}5.9947 \mathrm{a} \\
(1.4949)\end{array}$ & $\begin{array}{l}0.6744 \mathrm{~b} \\
(0.2766)\end{array}$ & $\begin{array}{l}12.1181 \mathrm{a} \\
(3.3832)\end{array}$ & $\begin{array}{c}0.4536 \\
{[37]}\end{array}$ \\
\hline $\begin{array}{l}\text { Countries with property rights index > } \\
\text { median }\end{array}$ & $\begin{array}{l}-0.6025 \\
(0.8916)\end{array}$ & $\begin{array}{c}-1.7726 \mathrm{a} \\
(0.3647)\end{array}$ & $\begin{array}{l}2.6081 \mathrm{a} \\
(0.9238)\end{array}$ & $\begin{array}{l}0.3291 \mathrm{~b} \\
(0.1395)\end{array}$ & $\begin{array}{l}10.8791 \mathrm{a} \\
(2.2572)\end{array}$ & $\begin{array}{c}0.4861 \\
{[44]}\end{array}$ \\
\hline
\end{tabular}

$\mathrm{a}=$ Significant at $1 \%$ level; $\mathrm{b}=$ Significant at $5 \%$ level; c=Significant at $10 \%$ level. 


\section{Appendix A}

This appendix describes the data sources used to calculate government ownership of banks in each country.

\begin{tabular}{|c|c|}
\hline Country & Sources of ownership data \\
\hline Afghanistan & $\begin{array}{l}\text { The Banker's Almanac, January } 1997 \text { Edition, Reed Information Services, London, U.K. } \\
\text { Thomson Bank Directory 1996, Thomson Financial Publishing. }\end{array}$ \\
\hline Algeria & $\begin{array}{l}\text { Algerian Embassy. } \\
\text { Jeune Afrique Economie N163, Special Banques, pg 79-88, Jan '93. } \\
\text { The AED African Financial Directory, 1987, Middle East Economic Digest Limited, London, U.K. } \\
\text { The Europa World Yearbook 1996, Europa Publications. } \\
\text { The Banker's Almanac, January } 1997 \text { Edition, Reed Information Services, London, U.K. }\end{array}$ \\
\hline Argentina & $\begin{array}{l}\text { America Economia, Latin America's Business Magazine, } 500 \text { Latin America's Largest Companies, } \\
\text { Annual Edition 1995/96. } \\
\text { The Banker's Almanac, January } 1997 \text { Edition, Reed Information Services, London, U.K. } \\
\text { Thomson Bank Directory 1996, Thomson Financial Publishing. }\end{array}$ \\
\hline Australia & $\begin{array}{l}\text { Annual Reports. } \\
\text { The Euromoney Bank Register 1996, 11th Edition, Euromoney Publications, London, U.K. } \\
\text { The Banker's Almanac, January 1997 Edition, Reed Information Services, London, U.K. } \\
\text { World Scope Global Disclosure Inc. } 1996 .\end{array}$ \\
\hline Austria & $\begin{array}{l}\text { Annual Reports. } \\
\text { Major Financial Institutions of Europe 1995/96, Graham \& Whiteside. } \\
\text { Moody's International Company Data, Moody's Investors Service, } 1994 \text { Version, New York, U.S.A. } \\
\text { The Banker's Almanac, January } 1997 \text { Edition, Reed Information Services, London, U.K. } \\
\text { The Euromoney Bank Register 1996, 11th Edition, Euromoney Publications, London, U.K. } \\
\text { The Europa World Yearbook 1996, Europa Publications. } \\
\text { World Scope Global Disclosure Inc. 1996. }\end{array}$ \\
\hline Bahrain & $\begin{array}{l}\text { Moody's International Company Data, Moody's Investors Service, } 1994 \text { Version, New York, U.S.A. } \\
\text { Telephonic Conversations. } \\
\text { The Banker's Almanac, January } 1997 \text { Edition, Reed Information Services, London, U.K. } \\
\text { The Banker's Almanac, January } 1997 \text { Edition, Reed Information Services, London, U.K. } \\
\text { The Euromoney Bank Register 1996, 11th Edition, Euromoney Publications, London, U.K. } \\
\text { Thomson Bank Directory 1996, Thomson Financial Publishing. }\end{array}$ \\
\hline Bangladesh & $\begin{array}{l}\text { The Europa World Yearbook 1996, Europa Publications. } \\
\text { The Banker's Almanac, January } 1997 \text { Edition, Reed Information Services, London, U.K. }\end{array}$ \\
\hline Belgium & $\begin{array}{l}\text { Annual Reports. } \\
\text { French Company Handbook 1996, Herald International Triune, SBF Paris Bourse, France. } \\
\text { Major Financial Institutions of Europe 1995/96, Graham \& Whiteside. } \\
\text { Moody’s International Company Data, Moody’s Investors Service, } 1994 \text { Version, New York, U.S.A. } \\
\text { The Banker's Almanac, January 1997 Edition, Reed Information Services, London, U.K. } \\
\text { The Euromoney Bank Register 1996, 11th Edition, Euromoney Publications, London, U.K. } \\
\text { The Europa World Yearbook 1996, Europa Publications. } \\
\text { World Scope Global Disclosure Inc. 1996. }\end{array}$ \\
\hline Bolivia & $\begin{array}{l}\text { Annual Reports. } \\
\text { America Economia, Latin America's Business Magazine, } 500 \text { Latin America's Largest Companies, } \\
\text { Annual Edition 1995/96. } \\
\text { The Banker's Almanac, January } 1997 \text { Edition, Reed Information Services, London, U.K. } \\
\text { Thomson Bank Directory 1996, Thomson Financial Publishing. }\end{array}$ \\
\hline Brazil & $\begin{array}{l}\text { America Economia, Latin America's Business Magazine, } 500 \text { Latin America's Largest Companies, } \\
\text { Annual Edition 1995/96. } \\
\text { The Banker's Almanac, January } 1997 \text { Edition, Reed Information Services, London, U.K. } \\
\text { Thomson Bank Directory 1996, Thomson Financial Publishing. }\end{array}$ \\
\hline
\end{tabular}




\begin{tabular}{|c|c|}
\hline Country & Sources of ownership data \\
\hline Bulgaria & The Banker's Almanac, January 1997 Edition, Reed Information Services, London, U.K. \\
\hline Canada & $\begin{array}{l}\text { Annual Reports. } \\
\text { Telephonic Conversations. } \\
\text { The Euromoney Bank Register 1996, 11th Edition, Euromoney Publications, London, U.K. } \\
\text { The Banker's Almanac, January 1997 Edition, Reed Information Services, London, U.K. } \\
\text { Thomson Bank Directory 1996, Thomson Financial Publishing. }\end{array}$ \\
\hline Chile & $\begin{array}{l}\text { America Economia, Latin America's Business Magazine, } 500 \text { Latin America's Largest Companies, } \\
\text { Annual Edition 1995/96. } \\
\text { The Banker's Almanac, January } 1997 \text { Edition, Reed Information Services, London, U.K. } \\
\text { Thomson Bank Directory 1996, Thomson Financial Publishing. }\end{array}$ \\
\hline China & $\begin{array}{l}\text { The Banker's Almanac, January } 1997 \text { Edition, Reed Information Services, London, U.K. } \\
\text { Thomson Bank Directory 1996, Thomson Financial Publishing. }\end{array}$ \\
\hline Colombia & $\begin{array}{l}\text { America Economia, Latin America's Business Magazine, } 500 \text { Latin America's Largest Companies, } \\
\text { Annual Edition 1995/96. } \\
\text { The Banker's Almanac, January } 1997 \text { Edition, Reed Information Services, London, U.K. } \\
\text { Thomson Bank Directory 1996, Thomson Financial Publishing. }\end{array}$ \\
\hline Costa Rica & $\begin{array}{l}\text { The Banker's Almanac, January } 1997 \text { Edition, Reed Information Services, London, U.K. } \\
\text { The Europa World Yearbook 1996, Europa Publications. } \\
\text { Thomson Bank Directory 1996, Thomson Financial Publishing. }\end{array}$ \\
\hline Cote D'Ivore & $\begin{array}{l}\text { Annual Reports. } \\
\text { Faxed Information. } \\
\text { Jeune Afrique Economie N163, Special Banques, pg 79-88, Jan ‘93. } \\
\text { The Banker's Almanac, January } 1997 \text { Edition, Reed Information Services, London, U.K. } \\
\text { The Europa World Yearbook 1996, Europa Publications. } \\
\text { Thomson Bank Directory 1996, Thomson Financial Publishing. }\end{array}$ \\
\hline Croatia & $\begin{array}{l}\text { The Euromoney Bank Register 1996, 11th Edition, Euromoney Publications, London, U.K. } \\
\text { The Banker's Almanac, January } 1997 \text { Edition, Reed Information Services, London, U.K. }\end{array}$ \\
\hline Cyprus & The Banker's Almanac, January 1997 Edition, Reed Information Services, London, U.K. \\
\hline Czech Republic & $\begin{array}{l}\text { Essinger, James, Eastern European Banking, 1st Edition 1994, Published by Chapman \& Hall, } \\
\text { London, U.K. } \\
\text { The Banker's Almanac, January } 1997 \text { Edition, Reed Information Services, London, U.K. }\end{array}$ \\
\hline Denmark & $\begin{array}{l}\text { Annual Reports. } \\
\text { Major Financial Institutions of Europe 1995/96, Graham \& Whiteside. } \\
\text { The Euromoney Bank Register 1996, 11th Edition, Euromoney Publications, London, U.K. } \\
\text { The Banker's Almanac, January 1997 Edition, Reed Information Services, London, U.K. }\end{array}$ \\
\hline $\begin{array}{l}\text { Dominican } \\
\text { Republic }\end{array}$ & $\begin{array}{l}\text { Hoover's Masterlist of Major Latin American Companies 1996-1997, The Reference Press, Tx, } \\
\text { U.S.A. } \\
\text { The Banker's Almanac, January } 1997 \text { Edition, Reed Information Services, London, U.K. } \\
\text { Thomson Bank Directory 1996, Thomson Financial Publishing. }\end{array}$ \\
\hline Egypt & $\begin{array}{l}\text { Annual Reports. } \\
\text { Jeune Afrique Economie N163, Special Banques, pg 79-88, Jan ' } 93 . \\
\text { The AED African Financial Directory, 1987, Middle East Economic Digest Limited, London, U.K. } \\
\text { The Euromoney Bank Register 1996, 11th Edition, Euromoney Publications, London, U.K. } \\
\text { The Banker's Almanac, January 1997 Edition, Reed Information Services, London, U.K. } \\
\text { The Europa World Yearbook 1996, Europa Publications. }\end{array}$ \\
\hline El Salvador & $\begin{array}{l}\text { Hoover's Masterlist of Major Latin American Companies 1996-1997, The Reference Press, Tx, } \\
\text { U.S.A. } \\
\text { Telephonic Conversations. } \\
\text { The Banker's Almanac, January } 1997 \text { Edition, Reed Information Services, London, U.K. } \\
\text { Thomson Bank Directory 1996, Thomson Financial Publishing. }\end{array}$ \\
\hline
\end{tabular}




\begin{tabular}{|c|c|}
\hline Country & Sources of ownership data \\
\hline Finland & $\begin{array}{l}\text { Annual Reports. } \\
\text { Electronic mail from the respective bank. } \\
\text { Major Financial Institutions of Europe 1995/96, Graham \& Whiteside. } \\
\text { Moody's International Company Data, Moody's Investors Service, } 1994 \text { Version, New York, U.S.A. } \\
\text { Telephonic Conversations. } \\
\text { The Banker's Almanac, January } 1997 \text { Edition, Reed Information Services, London, U.K. } \\
\text { The Euromoney Bank Register 1996, 11th Edition, Euromoney Publications, London, U.K. } \\
\text { The Europa World Yearbook 1996, Europa Publications. } \\
\text { World Scope Global Disclosure Inc 1996. }\end{array}$ \\
\hline France & $\begin{array}{l}\text { Annual Reports. } \\
\text { Telephonic Conversations. } \\
\text { Major Financial Institutions of Europe 1995/96, Graham \& Whiteside. } \\
\text { French Company Handbook 1996, Herald International Triune, SBF Paris Bourse. } \\
\text { Moody's International Company Data, Moody's Investors Service, } 1994 \text { Version, New York, U.S.A. } \\
\text { The Banker's Almanac, January 1997 Edition, Reed Information Services, London, U.K. } \\
\text { The Euromoney Bank Register 1996, 11th Edition, Euromoney Publications, London, U.K. } \\
\text { World Scope Global Disclosure Inc 1996. }\end{array}$ \\
\hline Germany & $\begin{array}{l}\text { Annual Reports. } \\
\text { Germany's Top 5,000, } 1997 \text { Edition, Frankfurter Allgemeine Zeitung Gmbh Infomation Services. } \\
\text { The Banker's Almanac, January } 1997 \text { Edition, Reed Information Services, London, U.K. } \\
\text { The Euromoney Bank Register 1996, 11th Edition, Euromoney Publications, London, U.K. }\end{array}$ \\
\hline Greece & $\begin{array}{l}\text { Annual Reports. } \\
\text { Telephonic Conversations. } \\
\text { The Euromoney Bank Register 1996, 11th Edition, Euromoney Publications, London, U.K. } \\
\text { The Banker's Almanac, January 1997 Edition, Reed Information Services, London, U.K. } \\
\text { Thomson Bank Directory 1996, Thomson Financial Publishing. }\end{array}$ \\
\hline Guatemala & $\begin{array}{l}\text { Guia Bancaria Latinoamericana, 16th Edition 1996, Federacion Latinoamericana de Bancos, Bogota, } \\
\text { Colombia. } \\
\text { Hoover's Masterlist of Major Latin American Companies 1996-1997, The Reference Press, Tx, } \\
\text { U.S.A. } \\
\text { Thomson Bank Directory 1996, Thomson Financial Publishing. }\end{array}$ \\
\hline Honduras & $\begin{array}{l}\text { Hoover's Masterlist of Major Latin American Companies 1996-1997, The Reference Press, Tx, } \\
\text { U.S.A. } \\
\text { Telephonic Conversations. } \\
\text { The Banker's Almanac, January } 1997 \text { Edition, Reed Information Services, London, U.K. } \\
\text { Thomson Bank Directory 1996, Thomson Financial Publishing. }\end{array}$ \\
\hline Hong Kong & $\begin{array}{l}\text { Annual Reports. } \\
\text { Telephonic Conversations. } \\
\text { The Banker's Almanac, January } 1997 \text { Edition, Reed Information Services, London, U.K. } \\
\text { Asian Company Handbook, 1995/1996 Edition, Toyo Kenzai Inc., Tokyo, Japan . } \\
\text { The Euromoney Bank Register 1996, 11th Edition, Euromoney Publications, London, U.K. }\end{array}$ \\
\hline Hungary & $\begin{array}{l}\text { Essinger, James, Eastern European Banking, 1st Edition 1994, Published by Chapman \& Hall, } \\
\text { London, U.K. } \\
\text { The Euromoney Bank Register 1996, 11th Edition, Euromoney Publications, London, U.K. } \\
\text { The Banker's Almanac, January 1997 Edition, Reed Information Services, London, U.K. }\end{array}$ \\
\hline Iceland & $\begin{array}{l}\text { The Euromoney Bank Register 1996, 11th Edition, Euromoney Publications, London, U.K. } \\
\text { The Banker's Almanac, January } 1997 \text { Edition, Reed Information Services, London, U.K. }\end{array}$ \\
\hline India & $\begin{array}{l}\text { Bankers Handbook for Asia 1994-1995, Dataline Asia-Pacific Limited. } \\
\text { The Euromoney Bank Register 1996, 11th Edition, Euromoney Publications, London, U.K. } \\
\text { The Banker's Almanac, January 1997 Edition, Reed Information Services, London, U.K. }\end{array}$ \\
\hline Indonesia & $\begin{array}{l}\text { Annual Reports. } \\
\text { The Europa World Yearbook 1996, Europa Publications. } \\
\text { Moody’s International Company Data, Moody's Investors Service, } 1994 \text { Version, New York, U.S.A. } \\
\text { The Euromoney Bank Register 1996, 11th Edition, Euromoney Publications, London, U.K. } \\
\text { The Banker's Almanac, January 1997 Edition, Reed Information Services, London, U.K. } \\
\text { World Scope Global Disclosure Inc } 1996 .\end{array}$ \\
\hline
\end{tabular}




\begin{tabular}{|c|c|}
\hline Country & Sources of ownership data \\
\hline Iran & $\begin{array}{l}\text { The Europa World Yearbook 1996, Europa Publications. } \\
\text { The Banker's Almanac, January } 1997 \text { Edition, Reed Information Services, London, U.K. } \\
\text { Thomson Bank Directory 1996, Thomson Financial Publishing. }\end{array}$ \\
\hline Ireland & $\begin{array}{l}\text { Annual Reports. } \\
\text { Telephonic Conversations. } \\
\text { Faxed Information. } \\
\text { Major Financial Institutions of Europe 1995/96, Graham \& Whiteside. } \\
\text { Moody's International Company Data, Moody's Investors Service, } 1994 \text { Version, New York, U.S.A. } \\
\text { The Euromoney Bank Register 1996, 11th Edition, Euromoney Publications, London, U.K. } \\
\text { The Banker's Almanac, January 1997 Edition, Reed Information Services, London, U.K. } \\
\text { World Scope Global Disclosure Inc } 1996 . \\
\text { Financial Times' Companie Briefings, Internet }\end{array}$ \\
\hline Israel & $\begin{array}{l}\text { Telephonic Conversations. } \\
\text { Moody's International Company Data, Moody's Investors Service, } 1994 \text { Version, New York, U.S.A. } \\
\text { Major Financial Institutions of Europe 1995/96, Graham \& Whiteside. } \\
\text { The Euromoney Bank Register 1996, 11th Edition, Euromoney Publications, London, U.K. } \\
\text { The Banker's Almanac, January 1997 Edition, Reed Information Services, London, U.K. } \\
\text { Thomson Bank Directory 1996, Thomson Financial Publishing. }\end{array}$ \\
\hline Italy & $\begin{array}{l}\text { Annual Reports. } \\
\text { Telephonic Conversations. } \\
\text { Electronic Mail. } \\
\text { Major Financial Institutions of Europe 1995/96, Graham \& Whiteside. } \\
\text { Financial Times' Companie Briefings, Internet. } \\
\text { The Euromoney Bank Register 1996, 11th Edition, Euromoney Publications, London, U.K. } \\
\text { The Banker's Almanac, January 1997 Edition, Reed Information Services, London, U.K. }\end{array}$ \\
\hline Japan & $\begin{array}{l}\text { Japan Company Handbook, Spring 1997, Toyo Kenzai Inc., Tokyo, Japan. } \\
\text { The Euromoney Bank Register 1996, 11th Edition, Euromoney Publications, London, U.K. } \\
\text { The Banker's Almanac, January } 1997 \text { Edition, Reed Information Services, London, U.K. }\end{array}$ \\
\hline Jordan & $\begin{array}{l}\text { The Euromoney Bank Register 1996, 11th Edition, Euromoney Publications, London, U.K. } \\
\text { The Banker's Almanac, January } 1997 \text { Edition, Reed Information Services, London, U.K. } \\
\text { Thomson Bank Directory 1996, Thomson Financial Publishing. }\end{array}$ \\
\hline Kazakhstan & $\begin{array}{l}\text { The Banker's Almanac, January } 1997 \text { Edition, Reed Information Services, London, U.K. } \\
\text { Thomson Bank Directory 1996, Thomson Financial Publishing. }\end{array}$ \\
\hline Kenya & $\begin{array}{l}\text { Annual Reports. } \\
\text { The Europa World Yearbook 1996, Europa Publications. } \\
\text { The AED African Financial Directory, 1987, Middle East Economic Digest Limited, London, U.K. } \\
\text { The Euromoney Bank Register 1996, 11th Edition, Euromoney Publications, London, U.K. } \\
\text { The Banker's Almanac, January 1997 Edition, Reed Information Services, London, U.K. } \\
\text { Thomson Bank Directory 1996, Thomson Financial Publishing. }\end{array}$ \\
\hline Korea-South & $\begin{array}{l}\text { Financial Times' Companie Briefings, Internet. } \\
\text { The Banker's Almanac, January } 1997 \text { Edition, Reed Information Services, London, U.K. } \\
\text { The Euromoney Bank Register 1996, 11th Edition, Euromoney Publications, London, U.K. } \\
\text { Thomson Bank Directory 1996, Thomson Financial Publishing. }\end{array}$ \\
\hline Kuwait & $\begin{array}{l}\text { Faxed Information. } \\
\text { The Banker's Almanac, January } 1997 \text { Edition, Reed Information Services, London, U.K. } \\
\text { The Euromoney Bank Register 1996, 11th Edition, Euromoney Publications, London, U.K. } \\
\text { Thomson Bank Directory 1996, Thomson Financial Publishing. }\end{array}$ \\
\hline Laos & Thomson Bank Directory 1996, Thomson Financial Publishing. \\
\hline Lebanon & $\begin{array}{l}\text { The Banker's Almanac, January } 1997 \text { Edition, Reed Information Services, London, U.K. } \\
\text { The Euromoney Bank Register 1996, 11th Edition, Euromoney Publications, London, U.K. } \\
\text { Thomson Bank Directory 1996, Thomson Financial Publishing. }\end{array}$ \\
\hline Libya & $\begin{array}{l}\text { The Banker's Almanac, January } 1997 \text { Edition, Reed Information Services, London, U.K. } \\
\text { The Euromoney Bank Register 1996, 11th Edition, Euromoney Publications, London, U.K. } \\
\text { The AED African Financial Directory, 1987, Middle East Economic Digest Limited, London, U.K. }\end{array}$ \\
\hline
\end{tabular}




\begin{tabular}{|c|c|}
\hline Country & Sources of ownership data \\
\hline Macau & $\begin{array}{l}\text { Bankers Handbook for Asia 1994-1995, Dataline Asia-Pacific Limited. } \\
\text { The Banker's Almanac, January } 1997 \text { Edition, Reed Information Services, London, U.K. } \\
\text { Thomson Bank Directory 1996, Thomson Financial Publishing. }\end{array}$ \\
\hline Macedonia & The Banker's Almanac, January 1997 Edition, Reed Information Services, London, U.K. \\
\hline Malaysia & $\begin{array}{l}\text { Annual Reports. } \\
\text { The Banker's Almanac, January } 1997 \text { Edition, Reed Information Services, London, U.K. } \\
\text { The Euromoney Bank Register 1996, 11th Edition, Euromoney Publications, London, U.K. } \\
\text { Financial Times' Companie Briefings, Internet. }\end{array}$ \\
\hline Mexico & $\begin{array}{l}\text { Extel Financial Ltd., } 1995 . \\
\text { The Banker's Almanac, January } 1997 \text { Edition, Reed Information Services, London, U.K. } \\
\text { The Euromoney Bank Register 1996, 11th Edition, Euromoney Publications, London, U.K. }\end{array}$ \\
\hline Morocco & $\begin{array}{l}\text { Annual Reports. } \\
\text { The AED African Financial Directory, 1987, Middle East Economic Digest Limited, London, U.K. } \\
\text { The Banker's Almanac, January 1997 Edition, Reed Information Services, London, U.K. } \\
\text { The Euromoney Bank Register 1996, 11th Edition, Euromoney Publications, London, U.K. } \\
\text { Moroccan Embassy. } \\
\text { The Europa World Yearbook 1996, Europa Publications. } \\
\text { Hartland-Peel, Christopher, African Equities, Euromoney Publication PLC, 1996, London, U.K. } \\
\text { Jeune Afrique Economie N163, Special Banques, pg 79-88, Jan '93. } \\
\text { Thomson Bank Directory 1996, Thomson Financial Publishing. }\end{array}$ \\
\hline Netherlands & $\begin{array}{l}\text { Annual Reports. } \\
\text { Major Financial Institutions of Europe 1995/96, Graham \& Whiteside. } \\
\text { Telephonic Con.versations. } \\
\text { The Euromoney Bank Register 1996, 11th Edition, Euromoney Publications, London, U.K. } \\
\text { Thomson Bank Directory 1996, Thomson Financial Publishing. } \\
\text { Polk World Banking Profiles, } 1997 \text { Edition, Thomson Financial Publication, Skokie, IL, U.S.A. }\end{array}$ \\
\hline New Zealand & $\begin{array}{l}\text { The New Zealand Company Register, 1994-1995, Headliner Publishing Co., Christchurch, New } \\
\text { Zealand. } \\
\text { The Banker's Almanac, January } 1997 \text { Edition, Reed Information Services, London, U.K. } \\
\text { The Euromoney Bank Register 1996, 11th Edition, Euromoney Publications, London, U.K. } \\
\text { Thomson Bank Directory 1996, Thomson Financial Publishing. }\end{array}$ \\
\hline Nicaragua & $\begin{array}{l}\text { Hoover's Masterlist of Major Latin American Companies 1996-1997, The Reference Press, Tx, } \\
\text { U.S.A. } \\
\text { Telephonic Conversations. } \\
\text { The Banker's Almanac, January } 1997 \text { Edition, Reed Information Services, London, U.K. }\end{array}$ \\
\hline Nigeria & $\begin{array}{l}\text { Annual Reports. } \\
\text { The AED African Financial Directory, 1987, Middle East Economic Digest Limited, London, U.K. } \\
\text { The Banker's Almanac, January } 1997 \text { Edition, Reed Information Services, London, U.K. } \\
\text { The Euromoney Bank Register 1996, 11th Edition, Euromoney Publications, London, U.K. } \\
\text { Hartland-Peel, Christopher, African Equities, Euromoney Publication PLC, 1996, London, U.K. } \\
\text { Thomson Bank Directory 1996, Thomson Financial Publishing. } \\
\text { The Economist Intelligence Unit, ILT March 1995. }\end{array}$ \\
\hline Norway & $\begin{array}{l}\text { Annual Reports. } \\
\text { Telephonic Conversations. } \\
\text { The Euromoney Bank Register 1996, 11th Edition, Euromoney Publications, London, U.K. } \\
\text { Moody’s International Company Data, Moody's Investors Service, } 1994 \text { Version, New York, U.S.A. } \\
\text { World Scope Global Disclosure Inc 1996. } \\
\text { Financial Times' Companie Briefings, Internet. }\end{array}$ \\
\hline Oman & $\begin{array}{l}\text { Major Companies in the Arab World. } \\
\text { The Banker's Almanac, January } 1997 \text { Edition, Reed Information Services, London, U.K. } \\
\text { The Europa World Yearbook 1996, Europa Publications. }\end{array}$ \\
\hline Pakistan & $\begin{array}{l}\text { The Banker's Almanac, January } 1997 \text { Edition, Reed Information Services, London, U.K. } \\
\text { Bankers Handbook for Asia 1994-1995, Dataline Asia-Pacific Limited. }\end{array}$ \\
\hline
\end{tabular}




\begin{tabular}{|c|c|}
\hline Country & Sources of ownership data \\
\hline Panama & $\begin{array}{l}\text { America Economia, Latin America's Business Magazine, } 500 \text { Latin America's Largest Companies, } \\
\text { Annual Edition 1995/96. } \\
\text { The Banker's Almanac, January } 1997 \text { Edition, Reed Information Services, London, U.K. } \\
\text { Thomson Bank Directory 1996, Thomson Financial Publishing. }\end{array}$ \\
\hline Paraguay & $\begin{array}{l}\text { Telephonic Conversations. } \\
\text { Thomson Bank Directory 1996, Thomson Financial Publishing. } \\
\text { The Banker's Almanac, January } 1997 \text { Edition, Reed Information Services, London, U.K. } \\
\text { Hoover's Masterlist of Major Latin American Companies 1996-1997, The Reference Press, Tx, } \\
\text { U.S.A. }\end{array}$ \\
\hline Peru & $\begin{array}{l}\text { Telephonic Conversations. } \\
\text { Thomson Bank Directory 1996, Thomson Financial Publishing. } \\
\text { The Banker's Almanac, January } 1997 \text { Edition, Reed Information Services, London, U.K. } \\
\text { Hoover's Masterlist of Major Latin American Companies 1996-1997, The Reference Press, Tx, } \\
\text { U.S.A. } \\
\text { Moody's International Company Data, Moody's Investors Service, } 1994 \text { Version, New York, U.S.A. } \\
\text { LIBRO? }\end{array}$ \\
\hline Philippines & $\begin{array}{l}\text { The Euromoney Bank Register 1996, 11th Edition, Euromoney Publications, London, U.K. } \\
\text { The Banker's Almanac, January 1997 Edition, Reed Information Services, London, U.K. } \\
\text { Moody's International Company Data, Moody's Investors Service, } 1994 \text { Version, New York, U.S.A. } \\
\text { MC? }\end{array}$ \\
\hline Poland & $\begin{array}{l}\text { Annual Reports. } \\
\text { The Europa World Yearbook 1996, Europa Publications. } \\
\text { The Euromoney Bank Register 1996, 11th Edition, Euromoney Publications, London, U.K. } \\
\text { The Banker's Almanac, January 1997 Edition, Reed Information Services, London, U.K. } \\
\text { Moody's International Company Data, Moody's Investors Service, } 1994 \text { Version, New York, U.S.A. } \\
\text { Thomson Bank Directory 1996, Thomson Financial Publishing. }\end{array}$ \\
\hline Portugal & $\begin{array}{l}\text { Annual Reports. } \\
\text { Financial Times' Companie Briefings, Internet. } \\
\text { The Europa World Yearbook 1996, Europa Publications. } \\
\text { The Euromoney Bank Register 1996, 11th Edition, Euromoney Publications, London, U.K. }\end{array}$ \\
\hline Qatar & $\begin{array}{l}\text { The Europa World Yearbook 1996, Europa Publications. } \\
\text { Thomson Bank Directory 1996, Thomson Financial Publishing. }\end{array}$ \\
\hline Romania & $\begin{array}{l}\text { The Banker's Almanac, January } 1997 \text { Edition, Reed Information Services, London, U.K. } \\
\text { Essinger, James, Eastern European Banking, 1st Edition 1994, Published by Chapman \& Hall, } \\
\text { London, U.K. }\end{array}$ \\
\hline Russia & $\begin{array}{l}\text { Annual Reports. } \\
\text { Banks, 1996-1997, SVOP Publisherers, Moscow, Russia. } \\
\text { The Euromoney Bank Register 1996, 11th Edition, Euromoney Publications, London, U.K. } \\
\text { The Banker's Almanac, January 1997 Edition, Reed Information Services, London, U.K. } \\
\text { Thomson Bank Directory 1996, World Reference, Thomson Financial Publishing. }\end{array}$ \\
\hline Saudi Arabia & $\begin{array}{l}\text { Annual Reports. } \\
\text { The Europa World Yearbook 1996, Europa Publications. } \\
\text { The Euromoney Bank Register 1996, 11th Edition, Euromoney Publications, London, U.K. } \\
\text { The Banker's Almanac, January 1997 Edition, Reed Information Services, London, U.K. } \\
\text { Thomson Bank Directory 1996, World Reference, Thomson Financial Publishing. }\end{array}$ \\
\hline Senegal & $\begin{array}{l}\text { The AED African Financial Directory, 1987, Middle East Economic Digest Limited, London, U.K. } \\
\text { The Banker's Almanac, January } 1997 \text { Edition, Reed Information Services, London, U.K. } \\
\text { The Euromoney Bank Register 1996, 11th Edition, Euromoney Publications, London, U.K. } \\
\text { The Europa World Yearbook 1996, Europa Publications. } \\
\text { Thomson Bank Directory 1996, Thomson Financial Publishing. }\end{array}$ \\
\hline Singapore & $\begin{array}{l}\text { Asian Company Handbook, 1995/1996 Edition, Toyo Kenzai Inc., Tokyo, Japan. } \\
\text { Annual Reports. } \\
\text { The Banker's Almanac, January 1997 Edition, Reed Information Services, London, U.K. } \\
\text { The Euromoney Bank Register 1996, 11th Edition, Euromoney Publications, London, U.K. } \\
\text { The Europa World Yearbook 1996, Europa Publications. } \\
\text { Thomson Bank Directory 1996, Thomson Financial Publishing. }\end{array}$ \\
\hline
\end{tabular}




\begin{tabular}{|c|c|}
\hline Country & Sources of ownership data \\
\hline Slovakia & $\begin{array}{l}\text { The Banker's Almanac, January } 1997 \text { Edition, Reed Information Services, London, U.K. } \\
\text { The Euromoney Bank Register 1996, 11th Edition, Euromoney Publications, London, U.K. }\end{array}$ \\
\hline Slovenia & $\begin{array}{l}\text { The Banker's Almanac, January } 1997 \text { Edition, Reed Information Services, London, U.K. } \\
\text { The Euromoney Bank Register 1996, 11th Edition, Euromoney Publications, London, U.K. }\end{array}$ \\
\hline South Africa & $\begin{array}{l}\text { Annual Reports. } \\
\text { The Banker's Almanac, January } 1997 \text { Edition, Reed Information Services, London, U.K. } \\
\text { The Euromoney Bank Register 1996, 11th Edition, Euromoney Publications, London, U.K. } \\
\text { Thomson Bank Directory 1996, Thomson Financial Publishing. } \\
\text { Who Controls Whom in South Africa, Financial Mail Survey Dec. } 6 \text { 1996, South Africa. }\end{array}$ \\
\hline Spain & $\begin{array}{l}\text { Annual Reports. } \\
\text { Telephonic Conversations. } \\
\text { Financial Times' Companie Briefings, Internet. } \\
\text { Thomson Bank Directory 1996, Thomson Financial Publishing. } \\
\text { The Maxwell Espinosa Shareholder Directory, 7th Edition, 1994, Union Editorial, Madrid, Spain. } \\
\text { The Euromoney Bank Register 1996, 11th Edition, Euromoney Publications, London, U.K. }\end{array}$ \\
\hline Sri Lanka & $\begin{array}{l}\text { Annual Reports. } \\
\text { The Banker's Almanac, January } 1997 \text { Edition, Reed Information Services, London, U.K. } \\
\text { Thomson Bank Directory 1996, Thomson Financial Publishing. } \\
\text { Bankers Handbook for Asia 1994-1995, Dataline Asia-Pacific Limited. }\end{array}$ \\
\hline Sweden & $\begin{array}{l}\text { Annual Reports. } \\
\text { Electronic Mail. } \\
\text { Major Financial Institutions of Europe 1995/96, Graham \& Whiteside. } \\
\text { Financial Times' Companie Briefings, Internet. } \\
\text { Thomson Bank Directory 1996, Thomson Financial Publishing. } \\
\text { The Maxwell Espinosa Shareholder Directory, 7th Edition, 1994, Union Editorial, Madrid, Spain. } \\
\text { The Euromoney Bank Register 1996, 11th Edition, Euromoney Publications, London, U.K. } \\
\text { The Europa World Yearbook 1996, Europa Publications. } \\
\text { The Banker's Almanac, January 1997 Edition, Reed Information Services, London, U.K. }\end{array}$ \\
\hline Switzerland & $\begin{array}{l}\text { Annual Reports. } \\
\text { Telephonic Conversations. } \\
\text { Major Financial Institutions of Europe 1995/96, Graham \& Whiteside. } \\
\text { The Euromoney Bank Register 1996, 11th Edition, Euromoney Publications, London, U.K. } \\
\text { The Banker's Almanac, January 1997 Edition, Reed Information Services, London, U.K. } \\
\text { Moody's International Company Data, Moody's Investors Service, } 1994 \text { Version, New York, U.S.A. }\end{array}$ \\
\hline Syria & Thomson Bank Directory 1996, Thomson Financial Publishing. \\
\hline Taiwan & $\begin{array}{l}\text { Bankers Handbook for Asia 1994-1995, Dataline Asia-Pacific Limited. } \\
\text { The Banker's Almanac, January } 1997 \text { Edition, Reed Information Services, London, U.K. } \\
\text { The Euromoney Bank Register 1996, 11th Edition, Euromoney Publications, London, U.K. }\end{array}$ \\
\hline Tanzania & $\begin{array}{l}\text { The AED African Financial Directory, 1987, Middle East Economic Digest Limited, London, U.K. } \\
\text { The Banker's Almanac, January } 1997 \text { Edition, Reed Information Services, London, U.K. } \\
\text { The Euromoney Bank Register 1996, } 11 \text { th Edition, Euromoney Publications, London, U.K. } \\
\text { The Europa World Yearbook 1996, Europa Publications. } \\
\text { Thomson Bank Directory 1996, Thomson Financial Publishing. }\end{array}$ \\
\hline Thailand & $\begin{array}{l}\text { Asian Company Handbook, 1995/1996 Edition, Toyo Kenzai Inc., Tokyo, Japan. } \\
\text { The Banker's Almanac, January } 1997 \text { Edition, Reed Information Services, London, U.K. } \\
\text { The Euromoney Bank Register 1996, 11th Edition, Euromoney Publications, London, U.K. } \\
\text { The MFC Investment Handbook, Thailand, } 1996 \text { Edition, The Mutual Fund Public Co., LTD. } \\
\text { Bangkok, Thailand. }\end{array}$ \\
\hline $\begin{array}{l}\text { Trinidad and } \\
\text { Tobago }\end{array}$ & $\begin{array}{l}\text { Telephonic Conversations. } \\
\text { Thomson Bank Directory 1996, Thomson Financial Publishing. }\end{array}$ \\
\hline Tunisia & $\begin{array}{l}\text { Jeune Afrique Economie N163, Special Banques, pg 79-88, Jan '93. } \\
\text { The AED African Financial Directory, 1987, Middle East Economic Digest Limited, London, U.K. } \\
\text { The Banker's Almanac, January } 1997 \text { Edition, Reed Information Services, London, U.K. } \\
\text { The Euromoney Bank Register 1996, 11th Edition, Euromoney Publications, London, U.K. } \\
\text { Thomson Bank Directory 1996, Thomson Financial Publishing. }\end{array}$ \\
\hline
\end{tabular}




\begin{tabular}{|c|c|}
\hline Country & Sources of ownership data \\
\hline Turkey & $\begin{array}{l}\text { Annual Reports } \\
\text { Faxed Information. } \\
\text { The Banker's Almanac, January 1997 Edition, Reed Information Services, London, U.K. } \\
\text { The Euromoney Bank Register 1996, 11th Edition, Euromoney Publications, London, U.K. } \\
\text { Thomson Bank Directory 1996, Thomson Financial Publishing. } \\
\text { The Europa World Yearbook 1996, Europa Publications. }\end{array}$ \\
\hline $\begin{array}{l}\text { United Arab } \\
\text { Emirates }\end{array}$ & $\begin{array}{l}\text { Major Companies in the Arab World. } \\
\text { The Banker's Almanac, January } 1997 \text { Edition, Reed Information Services, London, U.K. } \\
\text { The Euromoney Bank Register 1996, 11th Edition, Euromoney Publications, London, U.K. } \\
\text { Thomson Bank Directory 1996, Thomson Financial Publishing. }\end{array}$ \\
\hline United Kingdon & $\begin{array}{l}20 \mathrm{~F} \\
\text { Annual Reports. } \\
\text { Telephonic Conversations. } \\
\text { Major Financial Institutions of Europe 1995/96, Graham \& Whiteside. } \\
\text { The Euromoney Bank Register 1996, 11th Edition, Euromoney Publications, London, U.K. } \\
\text { The Company Guide, Hemmington Scott Publishers 1997, London, U.K. } \\
\text { World Scope Global Disclosure Inc 1996. }\end{array}$ \\
\hline Uruguay & $\begin{array}{l}\text { America Economia, Latin America's Business Magazine, } 500 \text { Latin America's Largest Companies, } \\
\text { Annual Edition 1995/96. } \\
\text { The Banker's Almanac, January } 1997 \text { Edition, Reed Information Services, London, U.K. } \\
\text { The Europa World Yearbook 1996, Europa Publications. } \\
\text { Thomson Bank Directory 1996, Thomson Financial Publishing. }\end{array}$ \\
\hline United States & World Scope Global Disclosure Inc 1996. \\
\hline Venezuela & $\begin{array}{l}\text { Annual Reports. } \\
\text { America Economia, Latin America's Business Magazine, } 500 \text { Latin America's Largest Companies, } \\
\text { Annual Edition 1995/96. } \\
\text { Hoover's Masterlist of Major Latin American Companies 1996-1997, The Reference Press, Tx, } \\
\text { U.S.A. } \\
\text { Thomson Bank Directory 1996, Thomson Financial Publishing. } \\
\text { The Banker's Almanac, January } 1997 \text { Edition, Reed Information Services, London, U.K. }\end{array}$ \\
\hline Vietnam & $\begin{array}{l}\text { The Banker's Almanac, January } 1997 \text { Edition, Reed Information Services, London, U.K. } \\
\text { The Europa World Yearbook 1996, Europa Publications. } \\
\text { Thomson Bank Directory 1996, Thomson Financial Publishing. }\end{array}$ \\
\hline Yugoslavia & The Banker's Almanac, January 1997 Edition, Reed Information Services, London, U.K. \\
\hline Zimbabwe & $\begin{array}{l}\text { Annual Reports. } \\
\text { Jeune Afrique Economie N163, Special Banques, pg 79-88, Jan '93. } \\
\text { The AED African Financial Directory, 1987, Middle East Economic Digest Limited, London, U.K. } \\
\text { The Banker's Almanac, January } 1997 \text { Edition, Reed Information Services, London, U.K. } \\
\text { The Euromoney Bank Register 1996, 11th Edition, Euromoney Publications, London, U.K. } \\
\text { Thomson Bank Directory 1996, Thomson Financial Publishing. } \\
\text { Hartland-Peel, Christopher, African Equities, Euromoney Publication PLC, 1996, London, U.K. }\end{array}$ \\
\hline
\end{tabular}

\section{References for General Sources:}

Polk World Banking Profiles, 1997 Edition, Thomson Financial Publication, Skokie, IL, USA

The Euromoney Bank Register 1996, 11th Edition, Euromoney Publications, London, U.K

The Banker's Almanac, January 1997 Edition, Reed Information Services, London, U.K

World Scope Global Disclosure Inc 1996.

International Financial Statistics, International Monetary Fund.

Japan Company Handbook, Spring 1997, Toyo Kenzai Inc., Tokyo, Japan

Germany's Top 5,000, 1997 Edition, Frankfurter Allgemeine Zeitung Gmbh Infomation Services

French Company Handbook 1996, Herald International Triune, SBF Paris Bourse

Asian Company Handbook, 1995/1996 Edition, Toyo Kenzai Inc.

Major Companies of the Arab World1994/1995, 18th Edition, Graham \& Trotman, London, U.K.

The MFC Investment Handbook, Thailand, 1996 Edition, The Mutual Fund Public Co., LTD. Bangkok, Thailand

Hartland-Peel, Christopher, African Equities, Euromoney Publication PLC, 1996, London, U.K.

Essinger, James, Eastern European Banking, 1st Edition 1994, Published by Chapman \& Hall, London, U.K.

Major Financial Institutions of Europe 1995/96, Graham \& Whiteside 